\title{
Benthic Foraminiferal Assemblage Formation: Theory and Observation for the European Arctic Margin
}

Paul Loubere ${ }^{1}$ and Shan Rayray ${ }^{2}$

seaberelou@yahoo.com

srayray@pierce.ctc.edu

1 Port Townsend, Washington 98368 USA

2 Pierce College, 9401 Farwest Dr. SW, Lakewood, WA 98498 USA

1

2

3

4

Abstract:

We use theory and observation to determine how benthic foraminiferal populations living in a range of sedimentary microenvironments are translated into fossil assemblages along the continental margin of the European Arctic. We examine downcore stained (cell tracker green and rose Bengal) and total species shell abundances through the sediment mixing (bioturbation) zone. This, in combination with porewater geochemical measurements, allows us to establish zones of production and destruction for species' shells, and deduce how the fossil record is being generated by the living community. For many taxa, shell production is high in the upper, oxic, sedimentary layer, but destruction in this zone is also high. Hence, contribution to the fossil record is biased to more infaunal populations and species. Taxa producing near, or below, the anoxic boundary of the sediments are particularly important to the developing fossil record of the fjord environment. We find that taxon relative and absolute abundances change continuously through the biologically active sediment profile. This has implications for reconstructing paleoenvironments using benthic foraminiferal assemblages, and potentially for the geochemistry of individual fossil taxa.

Keywords: benthic foraminifera, Arctic European margin, foraminiferal assemblages, microfossil preservation, benthic biogeochemistry 


\section{Introduction}

20 It has been long recognized that foraminiferal assemblages preserved in the marine record can

21 differ markedly from taxon standing stocks in the same location (e.g. Murray, 1976; Boltovskoy 22 and Wright, 1976; Scott and Medioli, 1980; Douglas et al., 1980; Mackensen and Douglas, 23 1989; Denne and Sen Gupta, 1989; Loubere and Gary, 1990; Murray, 1991; Mackensen et al.,

24 1995; Duros et al.,2012). This difference has been ascribed to diagenesis and differential 25 preservation of taxon shells (Smith, 1987; Loubere et al., 1993; Martin, 1999; Murray and Alve, 26 1999; for the northern North Atlantic: Steinsund and Hald, 1994; Hald and Steinsund, 1996; 27 Alve and Murray, 1997; Alve et al., 2011). It will also be a product of differential rates of shell 28 production among species (standing stock abundance counts do not reflect relative production 29 rates among taxa; e.g. Scott and Medioli, 1980; Loubere, 1997).

30 For individual taxa, what enters the fossil record depends on an interplay of microhabitat 31 location, geochemical gradients in the sediments and bioturbation mixing of shells through the 32 reactive interval of the seabed. Foraminiferal production occurs in selected micro-environments 33 in the BAZ (biologically active zone, Jorissen et al., 1995; Jorissen, 1999; Loubere, 1997). This 34 production is filtered through different geochemical regimes which develop in the zone of active 35 sediment mixing. Organic carbon oxidation in the sediment profile regulates pore water oxygen 36 concentrations and the dissolution of carbonate (Emerson and Bender, 1981; Archer et al., 1989;

37 Aller, 1982; Reaves, 1986; Jahnke et al., 1994; Sarmiento and Gruber, 2006). The former 38 influences where different species of foraminiferal live (Loubere et al., 1993; Jorissen et al., 39 1995; Loubere, 1997), and the latter influences preservation of the shells those species generate 40 (Loubere, 1989; Loubere et al., 2011). 
Analysis of short lived radio-isotopes in the sediment profile has demonstrated that seabed bioturbation mixing is rapid (Sarmiento and Gruber, 2006). For instance, in most open ocean settings, with sedimentation rates generally between 1 and $50 \mathrm{~cm} / \mathrm{kyr}(0.01$ to 0.5 millimeters per year), $\mathrm{Pb}-210$ concentrations in the upper 5 to $10 \mathrm{~cm}$ of the sediments are homogenized in spite of a half-life of only about 22 years. This would imply that empty foraminiferal shell abundances and distributions will also be rapidly homogenized in the mixing zone. Abundance trends in the bioturbated layer could only exist if created by dynamic processes with rates significantly higher than that of the mixing. Such processes include foraminiferal production of shells, and geochemical reactions within the sediments (summary in Sarmiento and Gruber, 2006). Both of these are fast enough to impose abundance/concentration gradients on a well mixed medium such as surficial marine sediments.

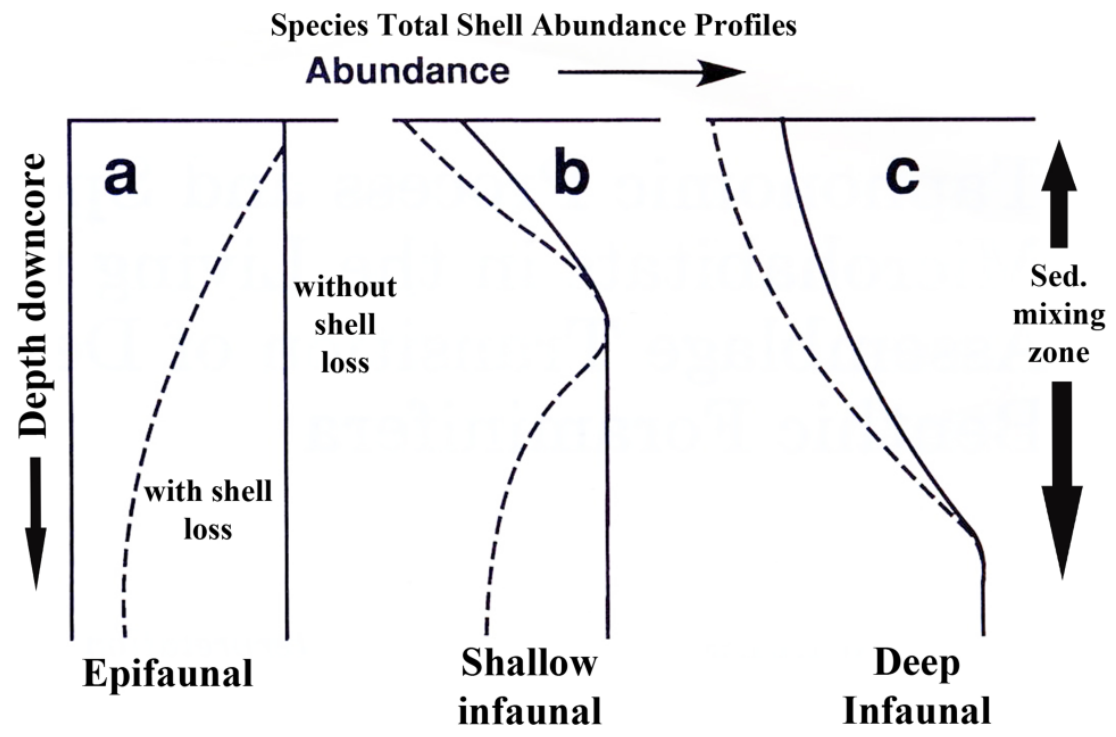

Figure 1. Modeled (Loubere, 1989) shell abundances in a sediment profile in which there is a well developed bioturbation zone and foraminiferal taxa inhabiting three levels of microhabitat (a: epifaunal, b: shallow infaunal, c: deeper infaunal). Production is limited to those habitation zones, but shell destruction is assumed to occur at a constant rate through the bioturbation zone, and the bioturbation process is modeled as in Guinasso and Schink (1975) for typical marine sediments. 
76 A simple model assumes that benthic foraminiferal species are broadly zoned into vertical

77 microhabitats (epifaunal, shallow infaunal, deep infaunal) (e.g. Jorissen, 1999) in the BAZ, that

78 sediments are uniformly bioturbated in that zone, that shells are destroyed at a constant rate

79 through the BAZ, and that the fossil assemblage is stabilized at the base of BAZ (bottom of the

80 bioturbation zone). Figure 1 shows that we may expect that foraminiferal taxa whose production

81 is concentrated in surface sediments will show decreasing total shell abundance down to the base

82 of the mixing zone, taxa which are shallow infaunal will show a subsurface peak in abundance,

83 while deeper infaunal taxa will show increasing abundance towards the level of fossil

84 assemblage stabilization.

85 The abundance profiles predicted by modeling are dynamic, with a steady state developed via 86 a balance of shell production and destruction rates, and a sediment 'diffusion' rate via the 87 vertical mixing caused by bioturbation.

88 The steepness of abundance gradients depends on having significant destructive processes in 89 the sediments, as shown in Fig. 1. At high loss rates, the shell abundance profiles will converge 90 on the standing stock (living specimen) abundance distribution in the sediments since shells will

91 be lost as soon as their foraminiferal producers die or abandon them (nothing survives to 92 fossilize).

93 It is important that in most open marine settings, shell abundance profiles within the sediment 94 bioturbation zone will not be the result of recent (within the time span averaged in the mixing 95 zone) changes in environmental conditions. This is because sedimentation rates in open ocean 96 settings are low compared to the mixing rate of sediments in the BAZ (Sarmiento and Gruber, 97 2006). Consequently, mixing will tend to rapidly homogenize concentration gradients in the 
sediments; and any gradients that are present must be actively maintained against the homogenization process.

The existence of foraminiferal shell abundance gradients within the mixing zone of sediments, should those be present, offers a means of analyzing where different taxa release shells into the sediment column, and the fate of those shells as they are processed prior to inclusion into the fossil record. It is clear that foraminiferal production is distributed among different microenvironments, that sediment mixing is rapid and efficient and that geochemical reactions driven by organic carbon oxidation occur at rates which will impact foraminiferal shell abundances in the sediment profile. So, we can expect that dynamically maintained taxon shell abundance gradients, similar to those shown in Fig. 1, are present in marine sediments, especially in settings with a limited supply of carbonate to buffer geochemically driven dissolution (e.g. sediments with higher terrigenous content).

\section{Study Location and Environmental Conditions}

. We test for the presence of taxon abundance gradients within the mixed layer of marine sediments using a sample transect along the European Arctic continental margin. The northern North Atlantic is a region where benthic foraminiferal assemblages have been used routinely for paleoceanic/paleoclimate research (e.g. Mackensen et al., 1985; Wollenburg, 1995; Husum and Hald, 2002; Ślubowska-Woldengen et al., 2008; Jernas, 2012 and Jernas et al., 2013; NorgaardPedersen and Mikkelsen, 2009), and a better understanding of assemblage formation processes will allow refined analysis of the sediment foraminiferal record.

The European Arctic margin is a setting in which the primary environmental variable influencing foraminiferal microhabitats and shell preservation is changing labile organic carbon flux to the seabed (Table 1). This varying flux generates progressive change in the habitation 
121

122

123

124

125

126

127

128

129

130

131

132

133

134

135

136

137

138

139

140

141

142

143

144

145

146

147

148

149

150

151

152

153

154

155

156

157

158

159

zone of the foraminifera and the geochemical profiles in the sediments which control shell

destruction. Using a combination of living (stained) and total foraminiferal shell abundance

profiles through the sediment mixing zone, along with geochemical analysis of pore waters, we

are able to assess foraminiferal shell processing in the sediment column, and test our

understanding of the way the fossil assemblage is formed.

Multi-core sediment profiles were collected in the Fram Strait and continental margin of

Svalbard (Fig. 2) to provide data to test assemblage formation theory. Table 1 lists sites and

conditions.

Table 1. Cores used in this study (see fig. 3). Bottom water (BW) temperature range from Conkright et al. (1994) and CTD at time of coring, bottom water oxygen range from microelectrodes at contact with sediments. Oxygen flux estimated using the smoothest oxygen profile at each site and following standard methodology (e.g. Froelich et al., 1979; Goloway and Bender, 1982; Sarmiento and Gruber, 2006). Results provide a relative sense of benthic organic carbon oxidation rates across the depth transect.

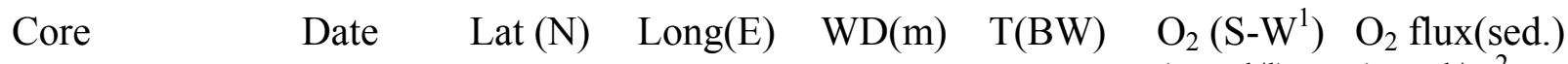

(umol/l) (umol $\left./ \mathrm{m}^{2} \mathrm{sec}\right)$

$\begin{array}{lllllrlr}\text { NP08-16-40 } & 8 / 21 / 08 & 78.9862 & 11.837 & 319 & 1.3-2 & 265-300 & -0.6976 \\ \text { JM08WP349 } & 8 / 13 / 08 & 75.989 & 13.644 & 1026 & 0-1 & 310-330 & -0.0181 \\ \text { JM08WP348 } & 8 / 12 / 08 & 75.9956 & 13.298 & 1264 & 0-1 & 310-330 & -0.0155 \\ \text { JM08WP347 } & 8 / 12 / 08 & 76.0023 & 12.8913 & 1500 & 0-1 & 310-330 & -0.0101 \\ \text { JM08WP337 } & 8 / 9 / 08 & 78.1355 & 8.507 & 1733 & -1-1 & 300-340 & -0.0184 \\ \text { JM08WP339 } & 8 / 10 / 08 & 77.9955 & 5.9726 & 2343 & -1-1 & 300-340 & -0.0051 \\ \text { JM08WP344 } & 8 / 12 / 08 & 75.982 & 8.323 & 2288 & -1-1 & 310-330 & -0.0038 \\ \text { JM08WP340 } & 8 / 10 / 08 & 77.9953 & 5.3295 & 2633 & -1-1 & 300-340 & -0.0048 \\ \text { JM08WP341 } & 8 / 11 / 08 & 77.9958 & 4.124 & 2952 & -1-1 & 300-340 & -0.0032 \\ \text { JM08WP342 } & 8 / 11 / 08 & 75.9958 & 4.3265 & 3037 & -1-1 & 300-340 & -0.0073\end{array}$

1 sediment-water interface

At each site multicores were collected and sediment pore water oxygen concentrations were measured using microelectrodes (Fig. 3; Loubere et al., 2011). Microelectrode profiles for each site permitted estimation of oxygen fluxes into the sediments (Table 1), which reflects rates of 
using oxygen releases acid which causes

oxygen uptake and organic carbon oxidation.

Thus the oxygen fluxes are a proxy for relative amounts of labile organic carbon reaching the seabed. Varying organic carbon flux to the seabed is a useful way of changing

foraminiferal production and shell preservation in the BAZ as taxa respond to changing food supply and subsurface oxygen concentrations. Also, oxidation of organic matter in sediments drives geochemical gradients which cause carbonate dissolution in the subsurface (Emerson and Bender, 1981; Archer et al., 1989; summary: Sarmiento and Gruber, 2006).

It is important that respiration of organic matter

175 carbonate dissolution; while organic carbon respiration with other oxidants (nitrate, sulfate, 177 manganese and iron oxide) involves reactions

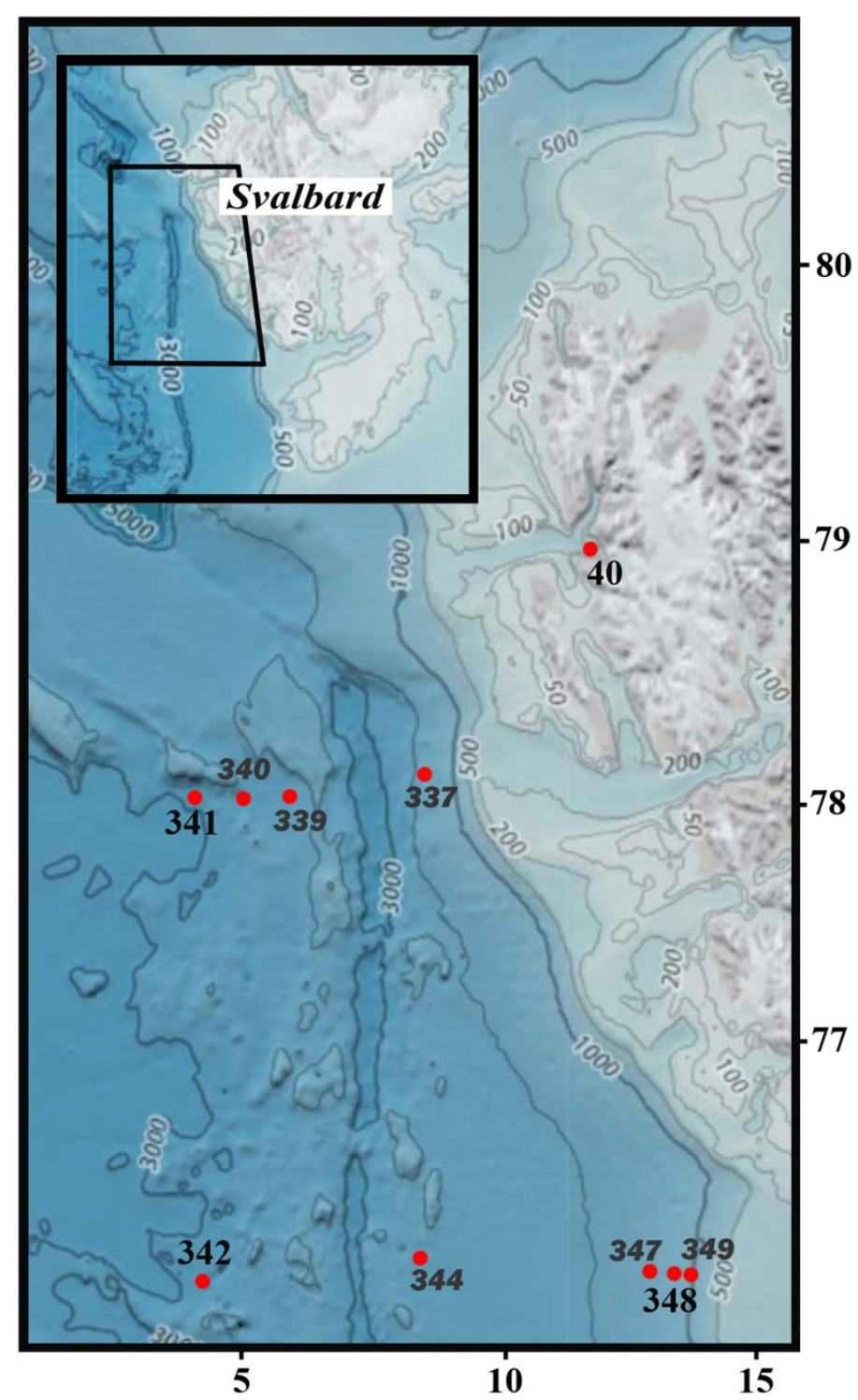

Figure 2. The sampling transect area, extending between Greenland and Svalbard (inset, trapezoid shows location of study area in larger map). Core site locations from Table 1 are marked, those analyzed for total shell abundances are labeled in bold.

178 which buffer the acid and favor carbonate preservation. So, the preservation of foraminifera

179 within the sediments will depend on the depth of the anoxic boundary, and the position of this 180 boundary with respect to the habitation zones of different foraminiferal taxa. For the transect 181 used in this study, the sediments are entirely oxic at greatest water depth while anoxic conditions 
182 are encountered within a centimeter of the

183 sediment-water interface in fjord locations

184 (Table 1, and below).

185

186

187 greater than $90 \%$ by weight, Kotwicki et al.,

188

189

190

191

192

193

194

195

196

197

198

199

200

201

202 processes.
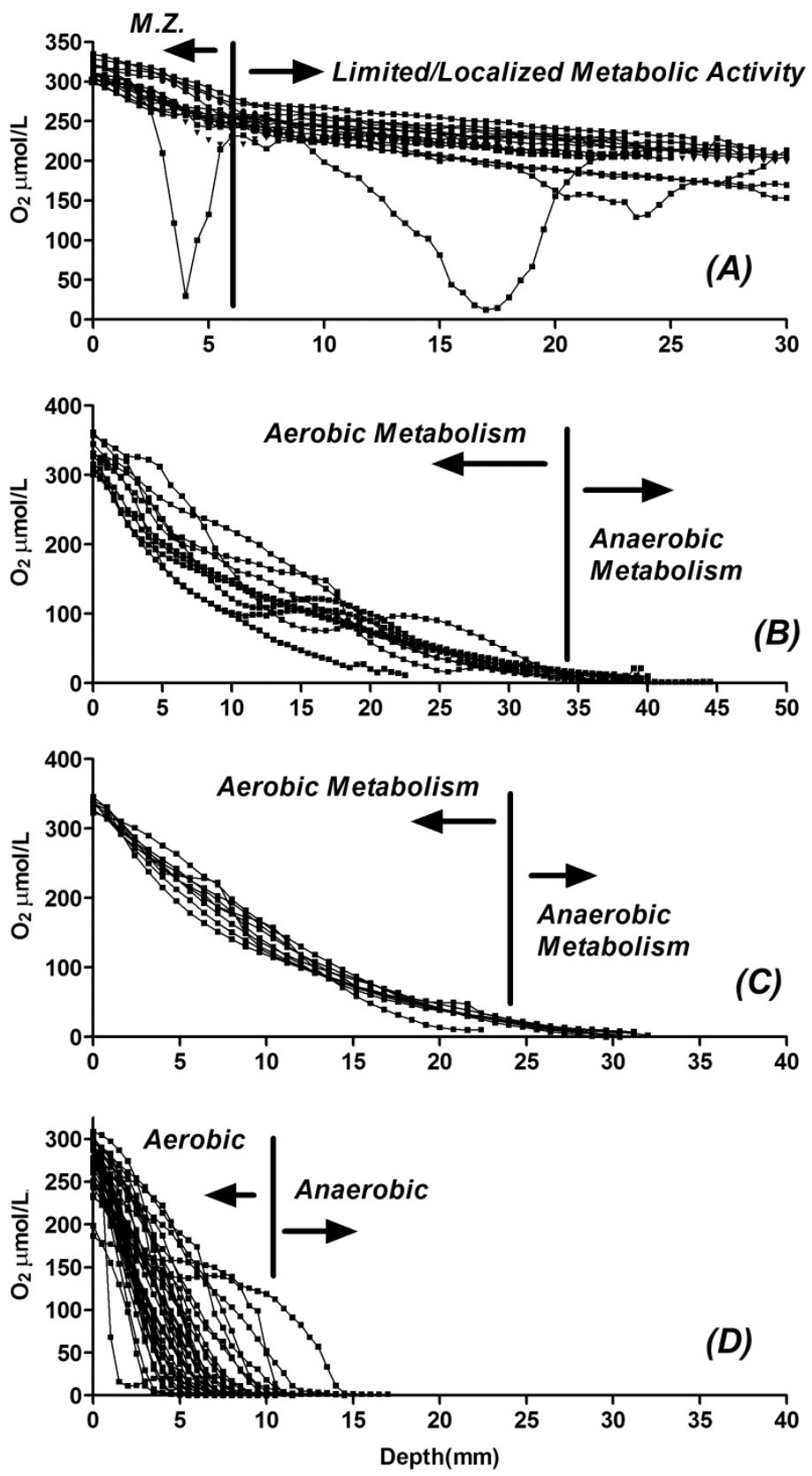

Figure 3. Pore water oxygen profiles for transect regions and coring sites (Table 1). (A) Abyssal sites [340,341,342,344] (MZ = metabolic zone), (B) mid-slope sites [337,347], (C) upper slope sites [348,349], (D) Kongsfjord sites [Loubere et al., 2011].

Available $\mathrm{Pb}-210$ activity profiles from the Fram Strait and Kongsfjord indicate that

bioturbation of the sediments is well developed in all environments we sampled to depths of at 
least $5 \mathrm{~cm}$ (Carignan et al., 2008; Zaborska et al., 2006). Even in the outer basin of Kongsfjord, near surface sediments were homogenous and there were abundant traces of polychaete burrowing (Zaborska et al., 2006; Loubere et al., 2011). This likely reflects the high bottom water oxygen concentrations at all locations which allow for extensive macrobenthic activity. Sedimentation rates for our transect appear to range from about 1.5-0.5 millimeter per year in the outer reaches of Kongsfjord (Zaborska et al., 2006; Skirbekk et al., 2010; Jernas et al., 2013) to considerably less than that on the slope and abyssal plain (e.g. Rasmussen et al., 2007;

Ślubowska-Woldengen et al., 2008).

It may seem paradoxical that bioturbation extends to 5 or more centimeters in locations, as in Kongsfjord, where anoxia is encountered just below the sediment-water interface as one might expect that sediment mixing would prevent steep oxygen gradients from developing; or that shallow anoxia would prevent deeper mixing. However, there is extensive evidence for biostructures extending well below the surface in sites with shallow anoxia (fjords of Svalbard, Loubere et al., 2011), and steep oxygen gradients can develop in spite of deeper sediment mixing because the diffusion rates for oxygen are much greater than the mixing rates of the sediments (Sarmiento and Gruber, 2006; sediment blending occurring over timescales of years to decades while oxygen diffusion rates provide responses in hours to days).

\section{Methods}

Sampling methods are detailed in Loubere et al. (2011). We collected sediments using a multicorer (model KC Denmark 72.021, six barrels: 110 x 800mm). We selected one core for pore-water oxygen profiling and sampling for foraminifera. At each site, the core surface was photographed for documentation of features and it was classified by the amount of surface that was occupied by obvious biostructures. Cores used in this study exhibited a sharp distinction in 
229 surface properties. Most cores at shallow depths had abundant biostructures (tubes, burrows, 230 pits), while deeper cores mostly had homogenous, nearly featureless, surfaces. Oxygen profiles 231 for the homogenous cores followed a classic, exponential, profile; while those from cores with 232 common biostructures were more complex.

233 We measured pore-water oxygen gradients using micro-electrodes and we subsampled the 234 sediments to determine the distribution of living benthic foraminiferal species using two staining 235 techniques (rose Bengal and cell tracker green (CTG)). It has been argued that CTG staining 236 (Berhard et al., 2006) best identifies individuals alive at time of sampling since staining depends 237 on active uptake across a cell membrane, while rose Bengal marks both living and recently dead 238 individuals.

239 Water column properties were measured at most sites by CTD (911 Plus CTD with compact 240 rosette; www.seabird.com). Pore-water oxygen concentrations were measured with Unisense 241 micro-electrodes positioned using a custom made manipulator frame in conjunction with a 242 temperature controlled seawater tank in which the top $15 \mathrm{~cm}$ of multicores were placed so as to 243 replicate seabed conditions. The tank was filled with local bottom water collected by CTD. The 244 apparatus allowed controlled probing of the core top in the vicinity of sediment structures and 245 had a positional accuracy of about $1 \mathrm{~mm}$ in the horizontal and $100 \mathrm{um}$ in the vertical.

246 Sediment for foraminiferal staining was taken from the multicore tubes used for oxygen 247 measurements. Syringe cores $(2.5 \mathrm{~cm}$ diameter $)$ were planted in the core and then extruded and 248 sliced at $0.5 \mathrm{~cm}$ intervals. Typically, 3 syringes were inserted in each multicore. For rose Bengal 249 staining the sediment samples were placed in zip-loc bags containing a solution of rose Bengal in 250 ethanol. For CTG staining the sediments were treated with a modification of the published 251 protocol (Bernhard et al., 2006). Sediment was placed in mini-centrifuge tubes along with the 
252 fluorescent probe and seawater at bottom water temperature. Tubes were sealed and then

253 incubated at appropriate temperatures for at least 8 hours before fixing with ethanol. Samples

254 were returned to the laboratory immediately after each cruise and stored in a refrigerator until

255 preparation for counting. Samples were wet sieved with distilled water over a $>63$ um screen and

256 placed in a wet picking tray for examination. The entire sample was scanned for stained

257 foraminifera. Only specimens showing more than half the test chambers with distinct stain were 258 counted.

259 Total (live + empty shells; unless these are specifically referred to) foraminiferal taxon 260 abundance counts were conducted on samples taken for rose Bengal staining. For these data, 261 samples were split using a tested, quantitative, micro-splitter, so as to have between 300 and 800

262 individuals present on the counting tray. Sample size was a uniform $2.45 \mathrm{~cm}^{3}$ and numbers 263 reported here have been corrected for number of sample splits.

264 Taxonomy follows studies conducted in the Svalbard margin (e.g. Korsun and Hald, 2000;

265 Wollenburg and Mackensen, 1998; Jernas et al., 2012), Loeblich and Tappan (1953) and

266 Cedhagen (2006). A full species list is in Appendix H.

\section{Results}

268 4.1 Living (stained) and Total Foraminiferal Abundance Profiles

269 4.1.1 Fjord Sites: stained counts in Appendices A and B, total counts in Appendices C-1,2

270 Stainable (cell tracker green) foraminifera were common in the sediments of Kongsfjord over

271 the multiple years we sampled (Loubere et al., 2011). Biostructures were also common, oxygen

272 penetration was to $1 \mathrm{~cm}$ or less in the sediments, there was visual evidence for sulfate reduction at

273 depth and the foraminiferal habitation zone was to about $3 \mathrm{~cm}$ for most taxa (Fig. 4). 
274 Biostructures seem to provide localized oxygenated microenvironments to $5 \mathrm{~cm}$ or more

275 (Loubere et al., 2011).

276 Stained communities are dominated by $N$.

277 labradorica, N. auricula, Globobulimina,

278 Fursenkoina and N. depressulus. The dominant

279 taxa in total assemblages are N. labradorica, $N$.

280 auricula, N. depressulus, Bolivina sp., I. helenae

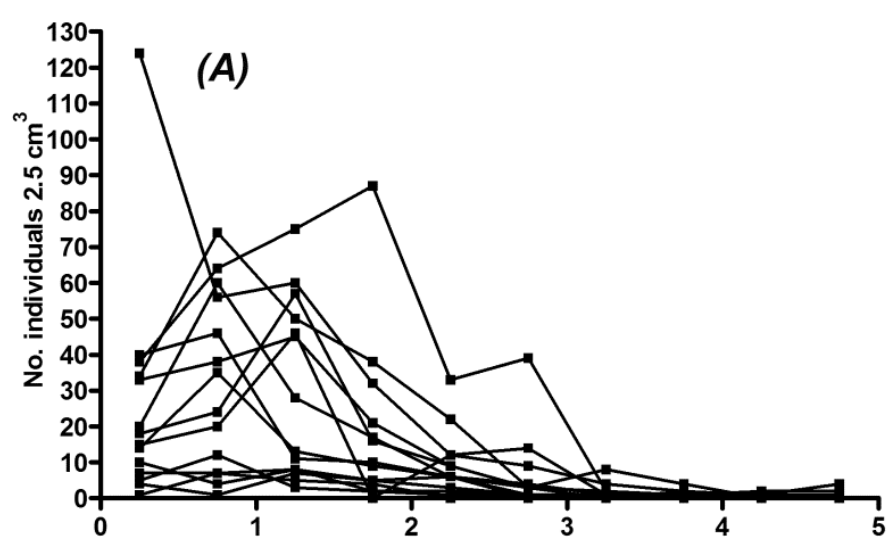

281 and Buliminella sp.

282 Many taxa show living abundance peaks

283 between 1 and $2 \mathrm{~cm}$ depth. A few, like $N$.

284 depressulus, show abundance peaks at greater

285 depth (Fig. 5). The latter include Globobulimina

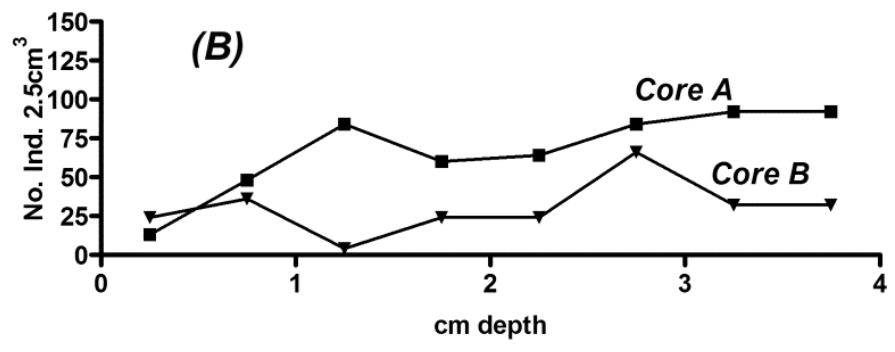

Figure 4. Stained and total shell data from Kongsfjord. (A) Total stained shells (CTG) for a suite of core sites in Kongsfjord (Loubere et al., 2011, sites and data in Appendix A). (B) Total unstained calcareous shells in two subcores for core NP-16-40 (Table 1).

288 In core NP08-13-40 the stained abundances of common taxa, like N. labradorica, follow the

289 pattern seen in previous studies (Loubere et al., 2011), and downcore total shell abundances

290 show increases with depth (Fig. 6).

291 In general, the total abundance profiles of individual taxa for NP08-13-40 show two patterns:

292 one in which taxon abundance peaks between 1 and $3 \mathrm{~cm}$ downcore, and another in which

293 abundance increases with depth (Fig.6, 7).

294

295 

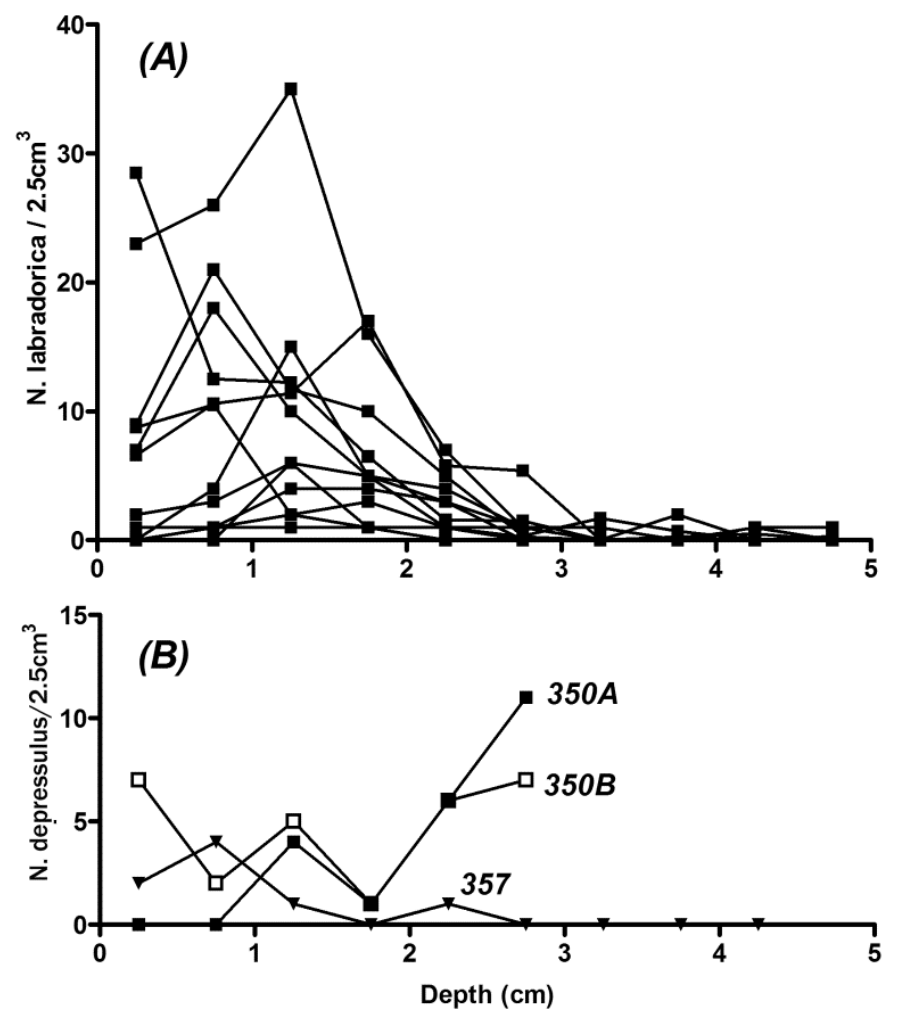

Figure 5. Stained (CTG) abundances of taxa from Konsfjord and the adjacent continental shelf. (A) N. labradorica in a suite of cores from Kongsfjord (Loubere et al., 2011, data in Appendix B). (B) N. depressulus from shelf cores (Table 1).

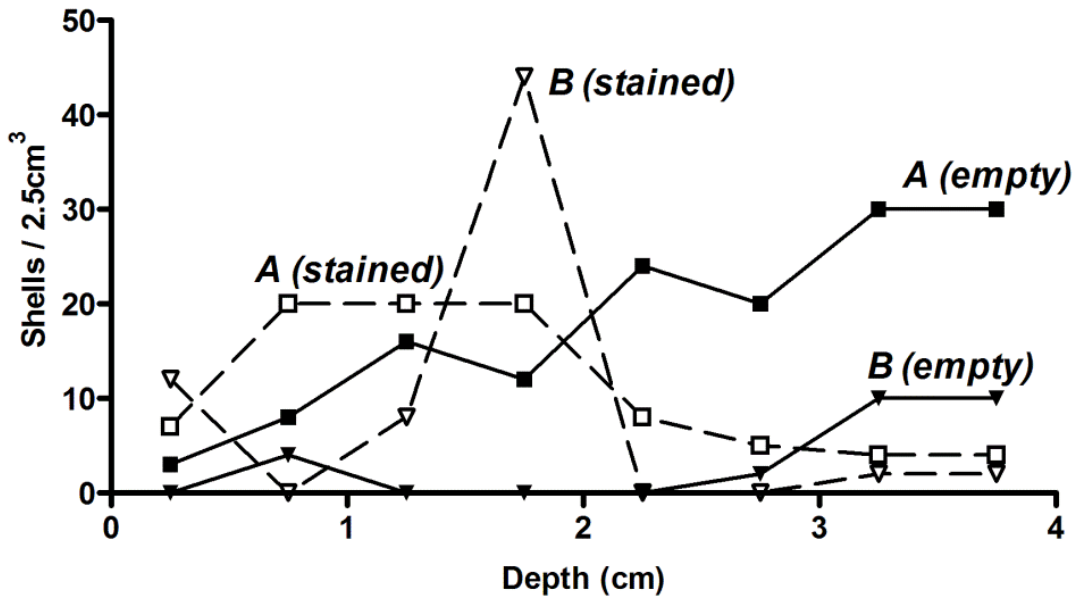

Figure 6. Stained (rose Bengal) and empty shell abundances of $N$. labradorica in Kongsfjord core NP08-16-40 for two sub-cores (A,B). 

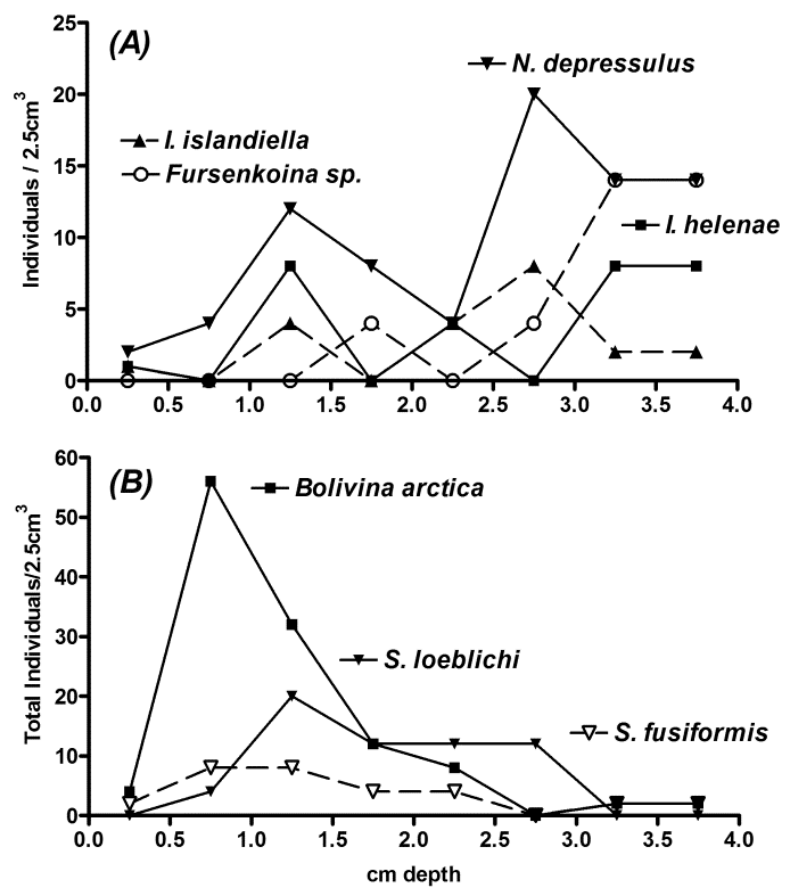

Figure 7. Empty shell abundances downcore for NP08-16-40 showing two groups of taxon abundance profiles. (A) taxa, in addition to $N$. labradorica, with abundances increasing downcore; (B) common taxa with abundance profiles similar to the living community abundance profiles seen in Kongsfjord (Fig. 4A).
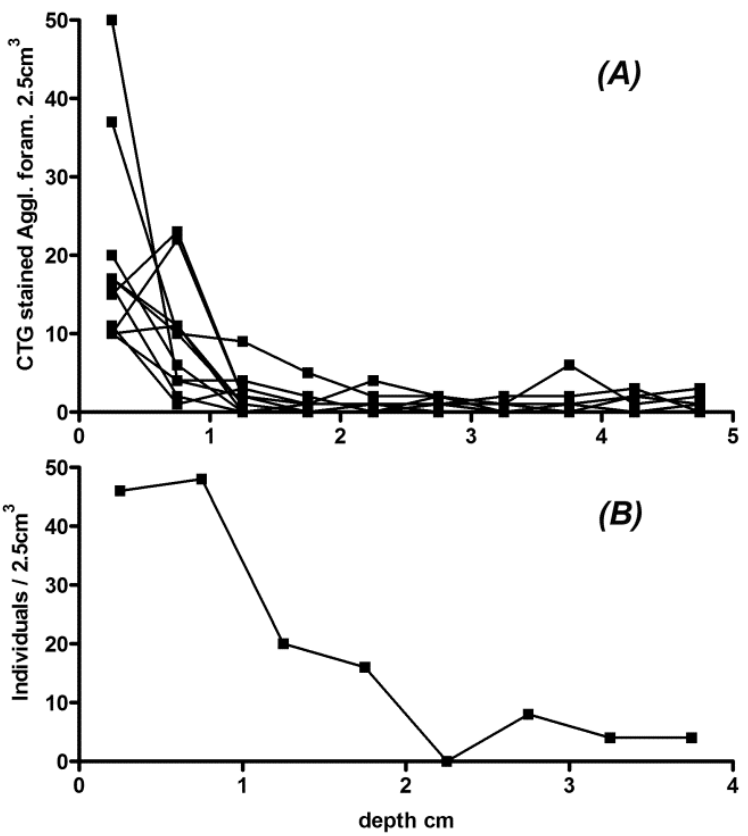

Figure 8. (A) stained (CTG) agglutinated taxa totals for a suite of cores in Kongsfjord (Loubere et al., 2011); (B) total agglutinated shells with depth for NP08-16-40. 
The stained and total abundance profiles for agglutinated taxa in the fjord environment differ from those of the calcareous species (Fig. 8). The agglutinates inhabit surface to shallow

321 subsurface microenvironments, and total shell abundances are highest at the surface while

322 declining precipitously downcore.

4.1.2 Continental Slope Sites: total counts in Appendices D-1,2

325

326

327

328

329

330
Stained records from continental slope

sites show most of the foraminiferal

population within the upper $2 \mathrm{~cm}$ of the

sediments (Fig. 9). There are scattered

smaller, deeper populations to at least 4 or

$5 \mathrm{~cm}$.

Total shell abundances follow a similar downcore trend to the stained populations

(Fig. 10). Common individual taxa show

three different abundance profiles:

declining downcore, variable abundance

downcore, and increasing abundance

downcore (Figs. 11-14).
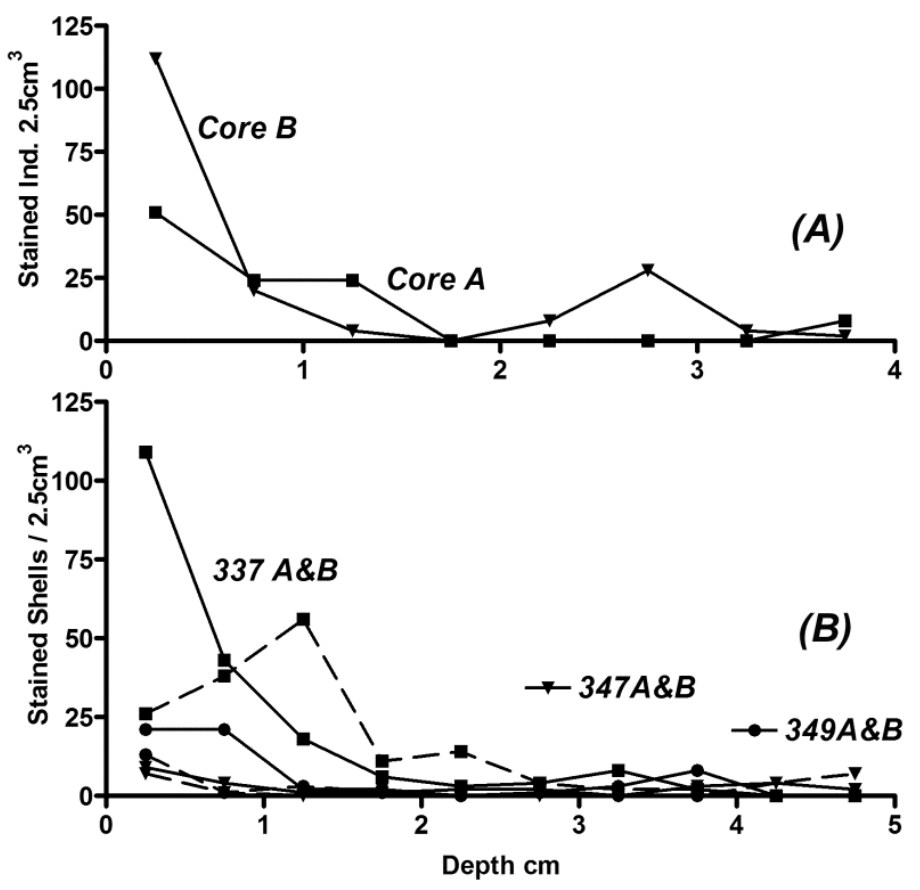

Figure 9. Stained foraminifera in slope cores (Table 1). (A) two subcores of WP08-348, (B) cores WP08-337, 347 and 349, two subcores for each have been combined. 


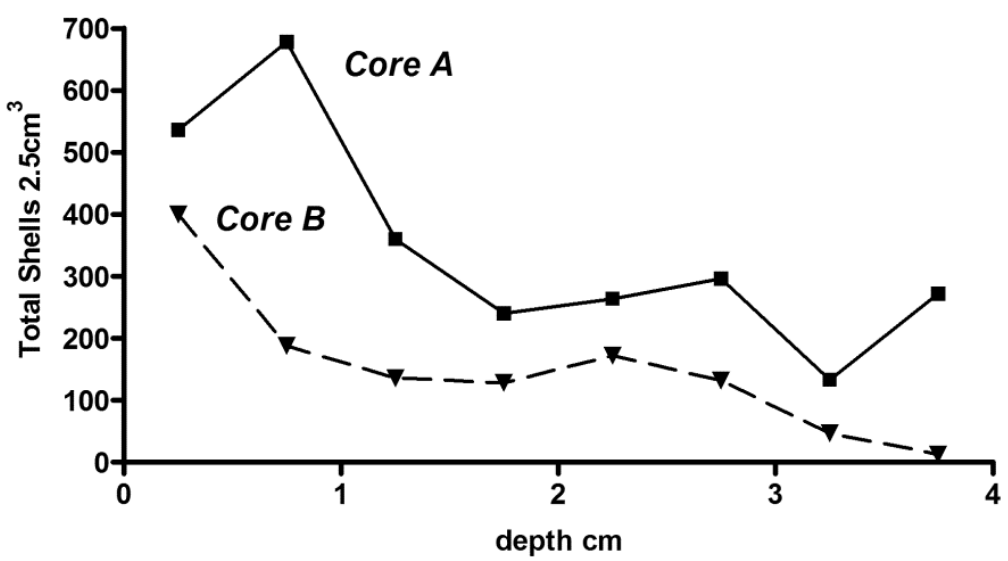

Figure 10. Total calcareous shells for slope core WP08-348.
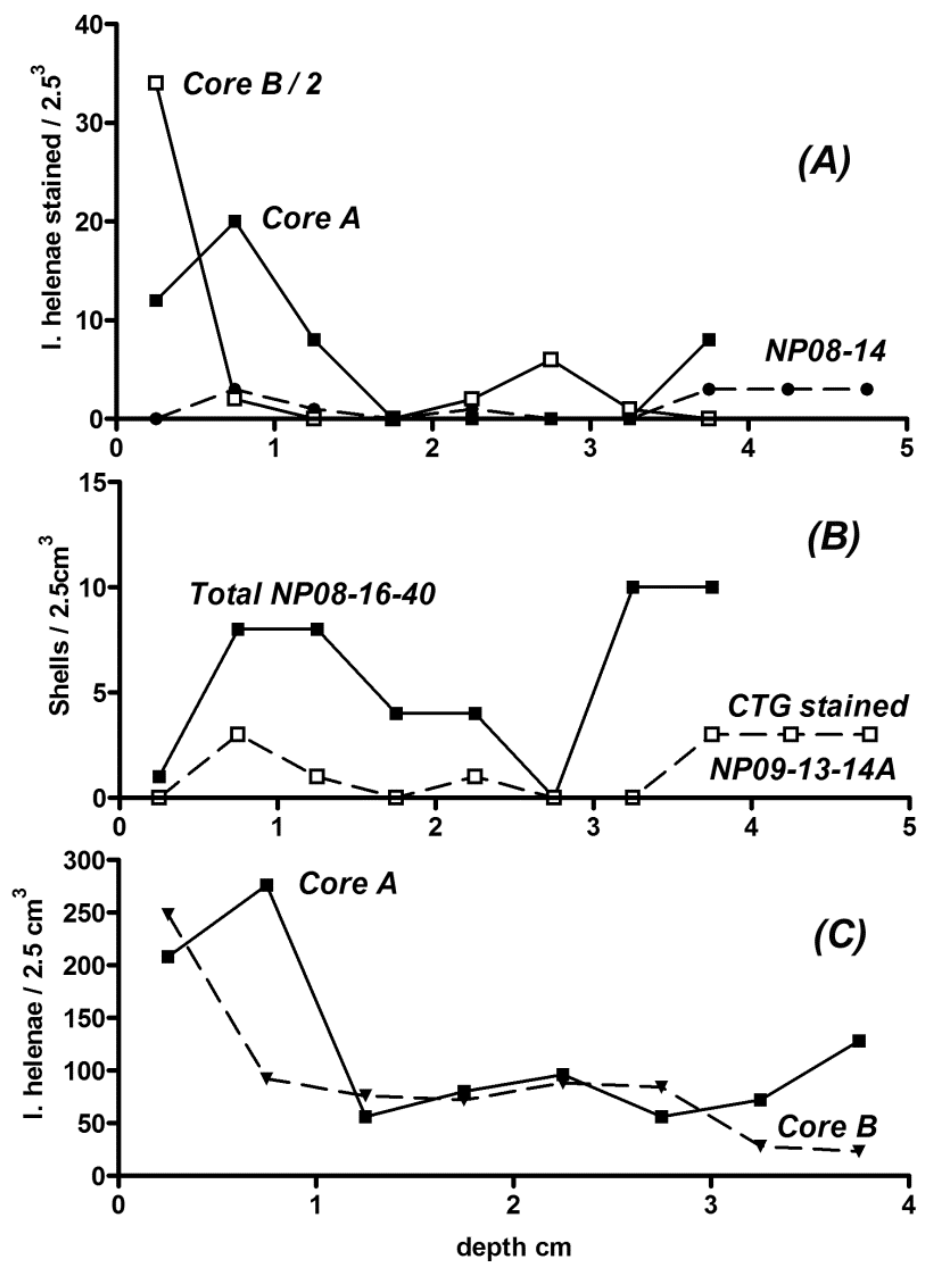

Figure 11. Stained and total shell abundances for the common slope taxon I. helenae. (A) stained abundances for slope site WP08-348 (subcore B values divided by 2); (B) total shell abundance in fjord site NP08-16-40, and stained (CTG) abundance for fjord site NP09-13-14; (C) total shell abundances for slope site WP08-348. 

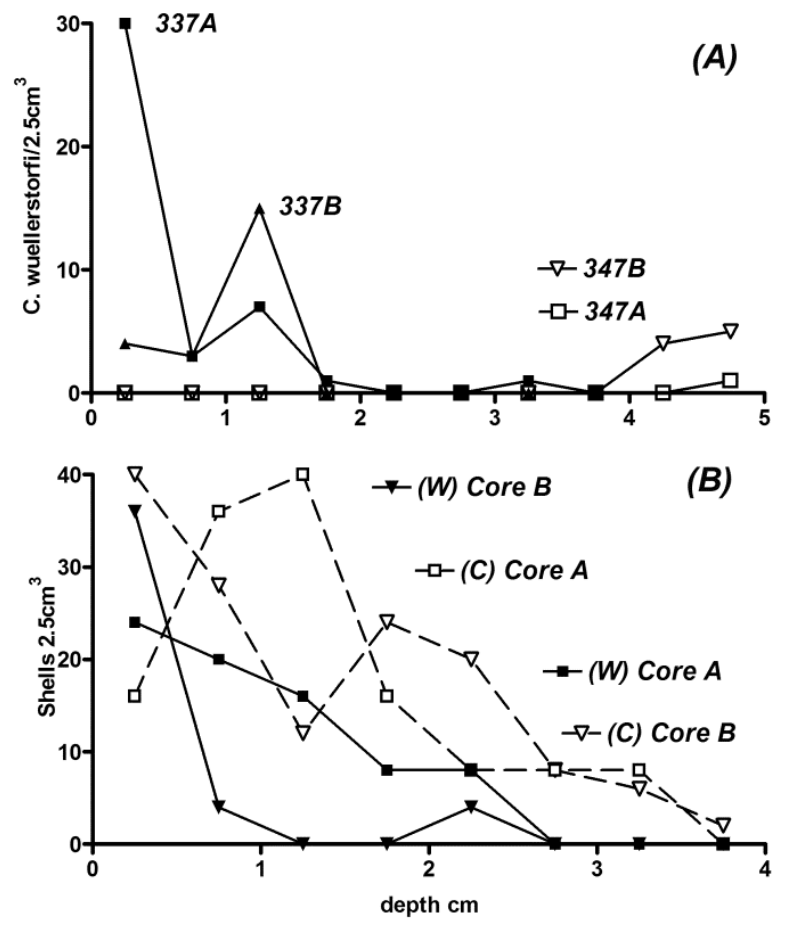

Figure 12. Cibicidoides taxa in slope cores. (A) stained individuals of $C$. wuellerstorfi for sites WP08-337 and 347. (B) C. wuellerstrofi (W) and C. pachyderma (C) total shell abundances in two subcores for site WP08-348.
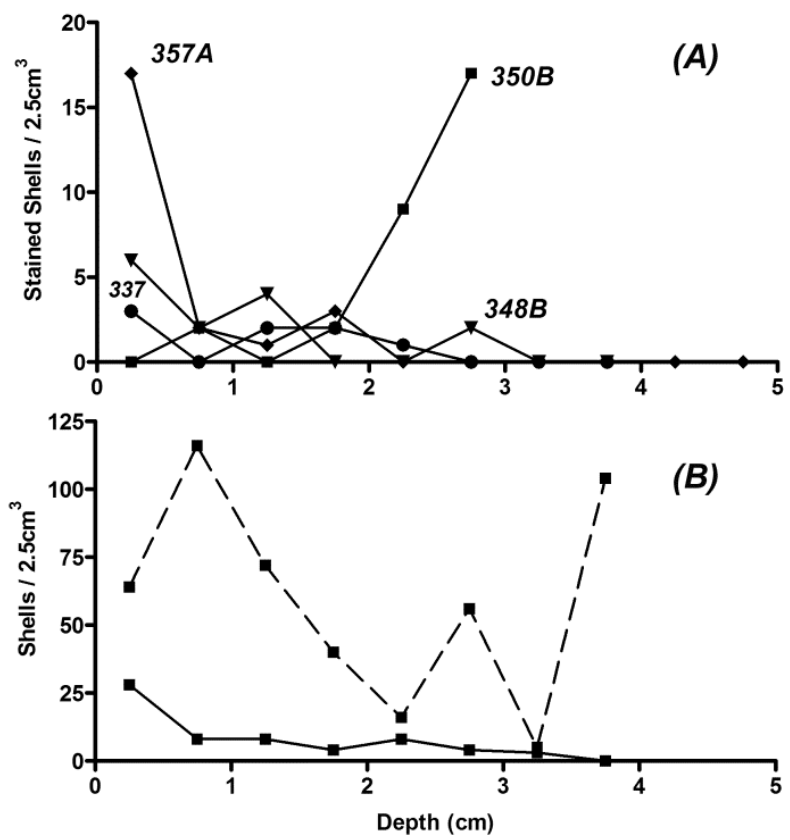

Figure 13. Abundance profiles for $C$. reniforme in slope cores. (A) stained individuals. (B) Total shells in two subcores of WP08-348 
Total shell profiles for Cibicidoides species decline downcore (Fig. 12), while those of $I$. helenae are most abundant at the surface, decline rapidly in the upper centimeter and then appear to stabilize below that (Fig. 11).

Cassidulina reniforme is a common taxon at both slope and abyssal sites on the Svalbard margin. Its stained abundances are highly variable in cores we examined with populations scattered to at least $3 \mathrm{~cm}$ depth (Fig. 13). Total shell abundance profiles are also highly variable for the slope site (Fig. 13), with

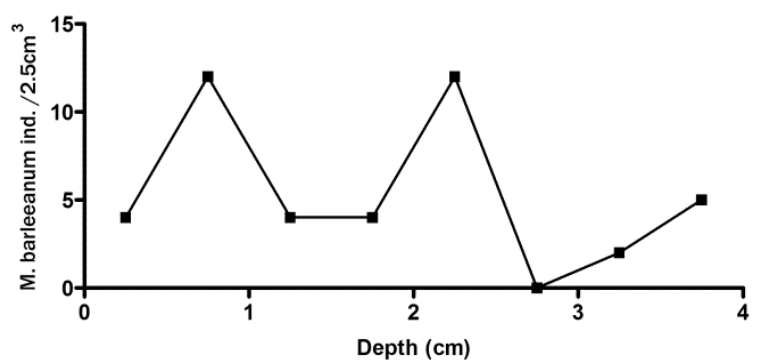

significant differences between sub-cores at the same location.

Melonis barleeanum is present at upper-slope to shelf sites and shows a similar total abundance profile to C. reniforme (Fig. 14).

4.1.3 Abyssal Sites: total counts in Appendices E and F At the abyssal sites we used (WP08-341 and 342), standing stocks of foraminifera were too low for reliable downcore stained abundance profiles at the small scale we used. Total abundance profiles of calcareous shells showed no significant downcore trends. However, abundance profiles for individual taxa did. Common taxa were C. wuellerstorfi, C. reniforme, Cibicidoides pachyderma, Oridorsalis sp., and E. exigua. Stained abundance profiles are available for several of these taxa from continental slope locations (C. wuellerstorfi, C. reniforme: Figs. 12, 13; Oridorsalis, E. exigua: Fig. 15).
Most of the taxa show stained abundance peaks in the upper $1.5 \mathrm{~cm}$ of the sediments. An exception is $C$. reniforme which shows significant populations to at least $3 \mathrm{~cm}$. 

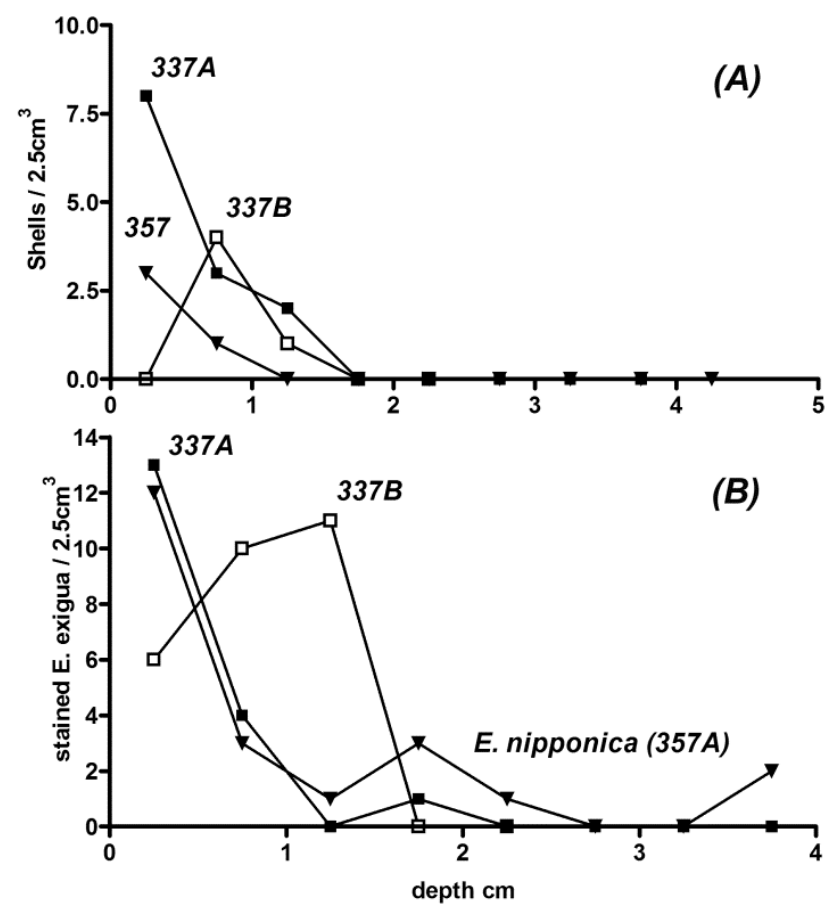

Figure 15. Stained abundances for the continental slope sites. (A) Oridorsalis sp. (B) E. exigua and E. nipponica. Site locations numbered as in Table 1.
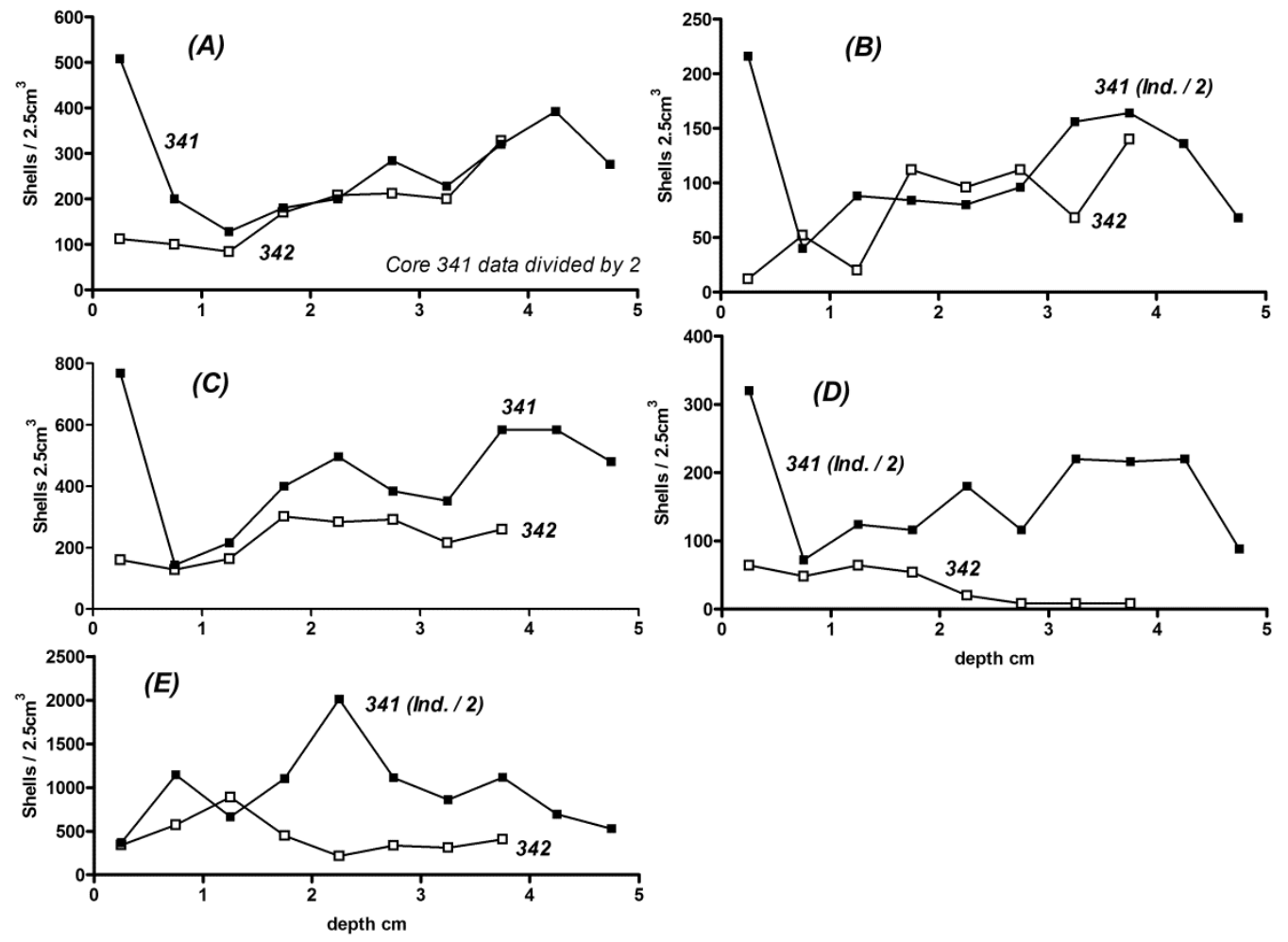

Figure 16. Total shell abundances for abyssal sites WP08-341 and 342. (A) $C$. wuellerstorfi, (B) C. pachyderma, (C) Oridorsalis sp., (D) E. exigua, and (E) C. reniforme. Data from core 341 are divided by 2 as indicated. 
Taxa have two patterns of total shell abundance at the abyssal sites we sampled: a surface peak with a minimum in the shallow subsurface and then an increase with depth and a subsurface peak with variable abundance downcore (Fig. 16). Note that absolute abundance of shells differs markedly between the sites we examined (difference in fine sediment fraction, and presumably clastic dilution) but general patterns are similar.

All of the common taxa except $C$. reniforme have abundance profiles with a maximum at the surface and a shallow subsurface minimum. They also show a modest increase in abundance downcore. This latter is not so consistent for E. exigua. In the case of C. reniforme, downcore abundances are more variable and there is a peak at greater depth with a minimum at the surface.

\subsection{Abundance Profiles and Generation of the Fossil Assemblage:}

A summary of microhabitat, seabed oxygen profiles, dissolution profile and foraminiferal taxon abundance profiles in relation to modeled profiles (Fig. 1) for the environments we sampled is given in Table 2 .

\subsubsection{Fjord Setting:}

Although bottom water concentrations are high, oxygen penetrates to less than $1 \mathrm{~cm}$ into the sediments because of a high flux of organic carbon to the seabed (Table 1; Fig. 3). Foraminiferal habitation zones extend to at least $4 \mathrm{~cm}$ depth even for taxa with demonstrated aversion to anoxia (Loubere et al., 2011). This indicates that the foraminifera take advantage of oxygenated biostructures, created by an abundant benthos, to inhabit otherwise hostile territory. The majority of the foraminiferal standing stock is in the upper $2 \mathrm{~cm}$ of the sediments. This is the interval in which most foraminiferal shell production must occur (Fig. 4). However, empty shell abundances are least near the surface and increase with depth. This type of abundance profile is that associated with input of shell material deeper in the mixing zone of the sediments (Fig. 1). 
Table 2. Observed taxon abundance profiles compared to model expectations for environments sampled.

\begin{tabular}{|c|c|c|c|c|c|c|}
\hline Setting & $\mathrm{O}_{2}$ gradient & Dissolution & Microhabitats & $\begin{array}{l}\text { Abundance Profile } \\
\text { Model type (fig. 1) }\end{array}$ & Taxa & Fig. ref. \\
\hline Fjord & $\begin{array}{l}\text { steep } \\
\text { anoxic }>1 \mathrm{~cm}\end{array}$ & $\begin{array}{l}\text { strong in upper } \\
\text { centimeter }\end{array}$ & $\begin{array}{l}\text { surficial, shallow } \\
\text { deeper infaunal }\end{array}$ & $\begin{array}{l}\text { shallow } \\
\text { deep }\end{array}$ & $\begin{array}{l}\text { Bolivina sp. } \\
\text { Fursenkoina sp. } \\
\text { N. labradorica } \\
\text { N. depressulus }\end{array}$ & $\begin{array}{l}7 \\
4-7\end{array}$ \\
\hline Slope & $\begin{array}{l}\text { moderate } \\
\text { anoxic }>2.5-3 \mathrm{~cm}\end{array}$ & $\begin{array}{l}\text { strong in upper } \\
3 \mathrm{~cm} .\end{array}$ & $\begin{array}{l}\text { surficial } \\
\text { surficial - shallow } \\
\text { mixed }\end{array}$ & $\begin{array}{l}\text { surficial } \\
\text { shallow }\end{array}$ & $\begin{array}{l}\text { Cibicidoides sp. } \\
\text { E. exigua } \\
\text { C. reniforme } \\
\text { M. barleeanum }\end{array}$ & $\begin{array}{l}9-12 \\
13 \\
14\end{array}$ \\
\hline Abyssal Plain & $\begin{array}{l}\text { limited to upper } \\
\mathrm{cm} ., \text { oxic to depth }\end{array}$ & in upper $1 / 2 \mathrm{~cm}$ & $\begin{array}{l}\text { surficial, scattered } \\
\text { infaunal } \\
\text { populations } \\
\text { signif. infaunal }\end{array}$ & $\begin{array}{l}\text { surficial+infaunal } \\
\text { mix } \\
\text { shallow }\end{array}$ & $\begin{array}{l}\text { Cibicidoides sp. } \\
\text { Oridorsalis sp. } \\
\text { E. exigua } \\
\text { C. reniforme }\end{array}$ & 15,16 \\
\hline
\end{tabular}


404 These data indicate that while foraminiferal production may be higher in the upper sediments,

405 shell destruction is higher there also. This is consistent with more intense shell degradation in

406 the oxic to sub-oxic portion of the sediment column (Fig. 3, Table 2), and with improved

407 preservation for anoxic conditions. In particular, lightly calcified taxa (Fig. 7, Bolivina sp.,

408 Globobulimina sp.) with most of the standing stock in the upper $2 \mathrm{~cm}$ of the sediments, do not

409 survive well and are attenuated in the developing fossil record. By contrast, those taxa which

410 have more substantial shells, habitation zones extending into the anoxic zone (N. labradorica;

411 Fig. 6) or with populations mainly at depth (N. depressulus; Fig. 7) preserve better and become

412 more significant in the fossil record. Preservation bias is towards the portion of a species'

413 production which occurs below the anoxic boundary in the sediments.

414 Production and preservation appear different for agglutinated foraminifera (Fig. 8). Standing 415 stock is concentrated to the sediment surface, and total abundance profiles show strong reduction 416 into the sediments. This indicates that microbial respiration of the organic matrix substrate of the 417 agglutinates is active under both oxic and anoxic conditions, and shell survival potential is low in 418 fjord settings of the type we sampled.

419

420

4.2.2 Assemblage Formation on the Continental Slope:

421 Organic carbon flux to the seabed is moderate in this setting, so oxygen penetrates to 2.5-3.5

$422 \mathrm{~cm}$ depth (Fig. 3). The foraminiferal habitation zone is predominantly in the upper $2 \mathrm{~cm}$, with

423 scattered populations at greater depth (Fig. 9). Total calcareous shell abundances (Fig. 10)

424 decline with depth, with sharp decline in the upper $2 \mathrm{~cm}$.

425 Most taxon total abundance profiles are similar to that for all shells (Figs. 11, 12), however

426 there are taxa which show peaks at depth (C. reniforme, Fig. 13; M. barleeanum, Fig. 14). 
427 Moderately high labile organic carbon flux to the sediments creates an active oxic metabolic

428 zone to between 2 and $3 \mathrm{~cm}$ depth (Fig. 3). Below this there is anoxic metabolism. Benthic

429 foraminifera inhabit mainly the oxic zone though some species are present to greater depth. This

430 is probably in association with biostructures.

431 Shell abundance profiles (Table 2) indicate that destructive processes are active through the

432 oxic zone of the sediments. The profiles are similar to that modeled for epi- to shallow infaunal

433 taxa subjected to shell loss through the mixing zone (Fig. 1). The result is attenuation of

434 foraminiferal shell abundances as they are mixed and processed through the bioturbation zone.

435 More variable abundance profiles are present for species with significant downcore production

436 (Table 2), especially at depths below $2-3 \mathrm{~cm}$ (below the main oxic respiration zone). Less

437 calcified species, such as $C$. reniforme, show fluctuating abundances downcore. This may be

438 because they produce concentrations of shells in scattered locations (e.g. Loubere and Gary,

439 1990; biostructures, Loubere et al., 2011) within the sediments and these are preferentially

440 degraded as they are mixed laterally, leading to irregular, patchy, sediment distribution.

\subsubsection{Assemblage Generation on the Abyssal Plain}

443 Organic carbon flux is low in this setting, so sediments are entirely oxic and respiration is

444 concentrated in the upper centimeter (Fig. 3). Radio-isotope tracers indicate active bioturbation

445 to at least $5 \mathrm{~cm}$ depth. At time of sampling, foraminiferal standing stocks were sparse compared

446 to the slope and fjord. The most common taxa in the sediment assemblage (empty shells) have

447 surface to near-surface habitation zones, but there is evidence for infaunal foraminiferal

448 production (e.g. C. wuellerstorfi, fig. 12). Nearly all the taxon total abundance profiles show

449 peaks at the surface with a subsurface minimum, but then abundance increases modestly with 
450 depth (fig. 16). This is seen at two sites with different locations and sedimentation

451 characteristics. The abundance profile form indicates that maximum production occurs near the

452 sediment surface, and that shell destruction occurs in the bioturbation zone, yielding downcore

453 decreases in taxon abundance as in the modeled profile for epifaunal taxa (fig.1). However, the

454 abundance profiles (fig. 16, Table 2) indicate that deeper in the sediments, where destructive

455 processes are limited, addition of shells from deeper populations of most taxa make up for some

456 of the lost material, resulting in increasing shell abundances downcore.

457 The abundance profiles show noticeable downcore variability. This may result from recent

458 shell production (over the summer season, sampling towards the end of the Arctic productive

459 season; Wassmann, 2001) in scattered subsurface locations and incomplete mixing, and

460 dissolution, of recently produced shells away from the production centers.

461

462 5. What Gets Into The Fossil Record

463 Fossil assemblages are typically examined in terms of percentages of taxa rather than absolute

464 sedimentary abundances. A simple way to assess the developing fossil assemblage is to compare

465 taxon relative abundances through the sediment mixing zone (Figs. 17-19).

466 For the settings examined here, the foraminiferal assemblages are dominated by relatively few

467 taxa. Overall, the same taxa remain dominant through the sediment column, but there are

468 noticeable differences in relative abundances through the sediment mixing zone. Downcore

469 changes can be ascribed to increasing representation by species with infaunal production, and

470 reductions in abundances of thin-walled and more delicate taxa. So, for example, in the fjord

471 setting Bolivina are common in surficial sediments, but are poorly represented several 


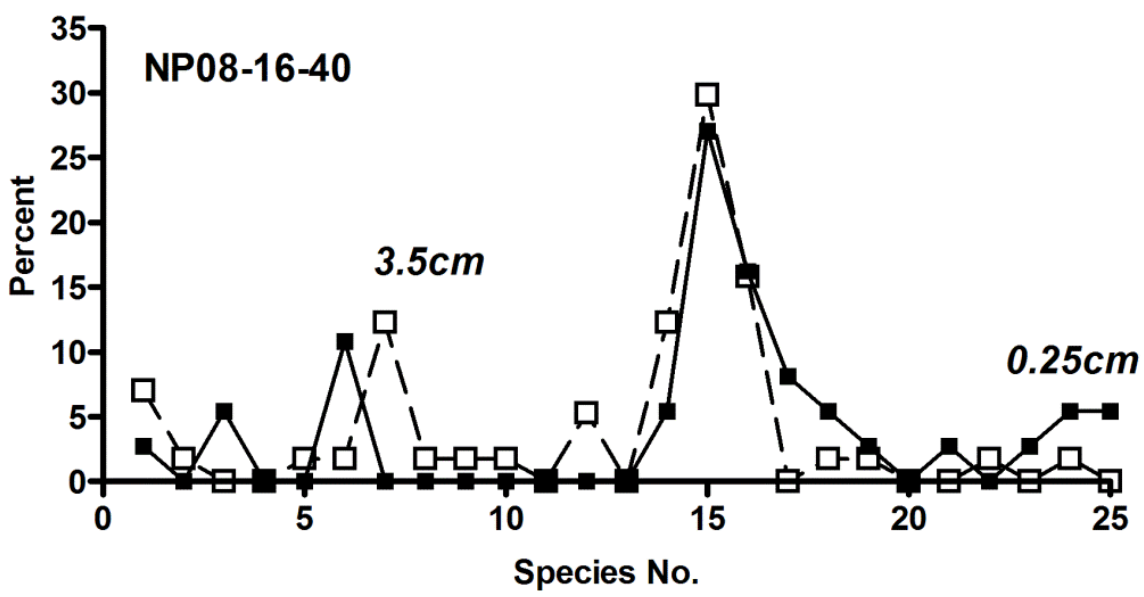

Figure 17. Taxon percents in surface and bottom samples from Kongsfjord core NP08-16-40. 1= I. helenae, $2=$ C. laevigata, $3=$ Gyroidina $\mathrm{sp}$., $5=$ B. pseudopunctata, $6=$ Bolivina arctica, $7=$ Fursenkoina sp., $8=$ Fursenkoina complanata, $9=$ Globobulimina auriculata, $10=$ G. turgida, 12 $=B$. tenerima, $14=N$. depressulus, $15=N$. labradorica, $16=N$. auricula, $17=$ Nonionella scapha, $18=C$. neoteretis, $21=C$. reniforme, $23=$ Epistominella sp., $24=$ Stainforthia fusiformis, 25 = Cassidulina/Islandiella sp. Complete taxon list in Appendix G.
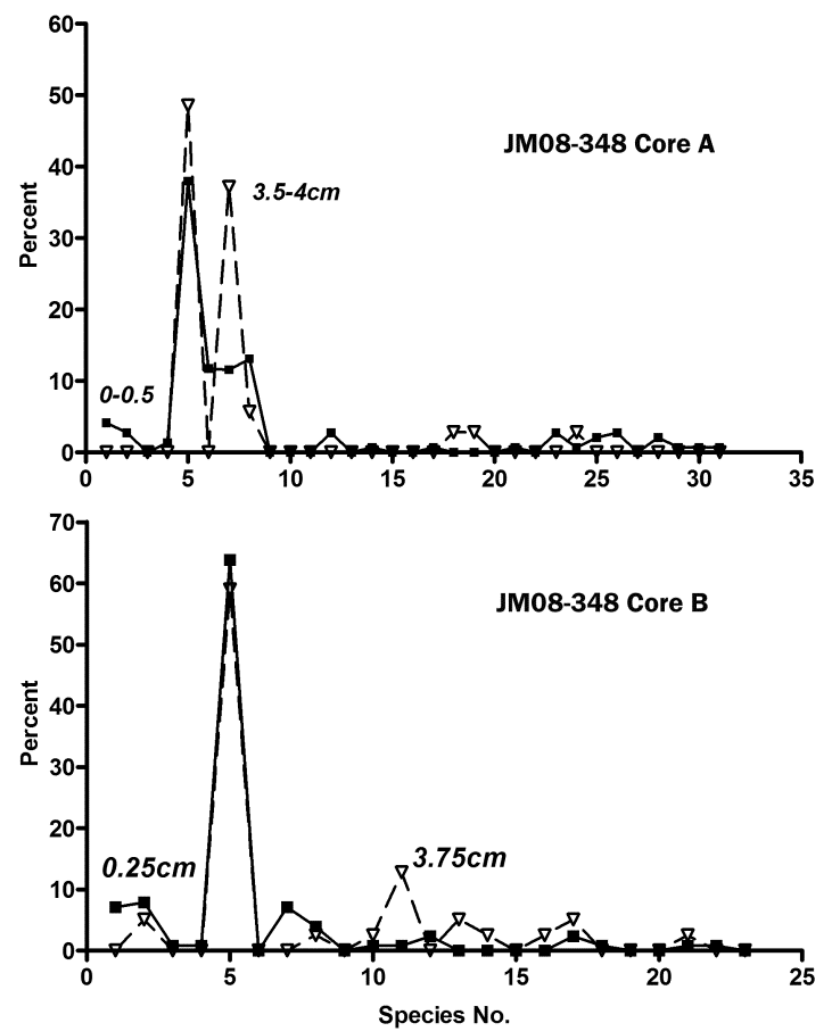

Figure 18. Taxon percents in surface and deeper samples for slope site JM08-348. Subcore A: $1=C$. wuellerstorfi, $2=C$. pachyderma, $5=I$. helenae, $6=I$. islandiella, $7=C$. reniforme, $8=C$. laevigata, $18=$ Oridorsalis sp., $19=P$. bulloides.

Subcore B: $1=C$. wuellerstorfi, $2=C$. pachyderma, $5=I$. helenae, $7=C$. reniforme, $11=M$. barleeanum, $13=F$. pseudopolymorphina, $14=$ Fursenkoina sp., $16=B$. tenerima, $17=P$. bulloides . Complete taxon list in Appendix G. 

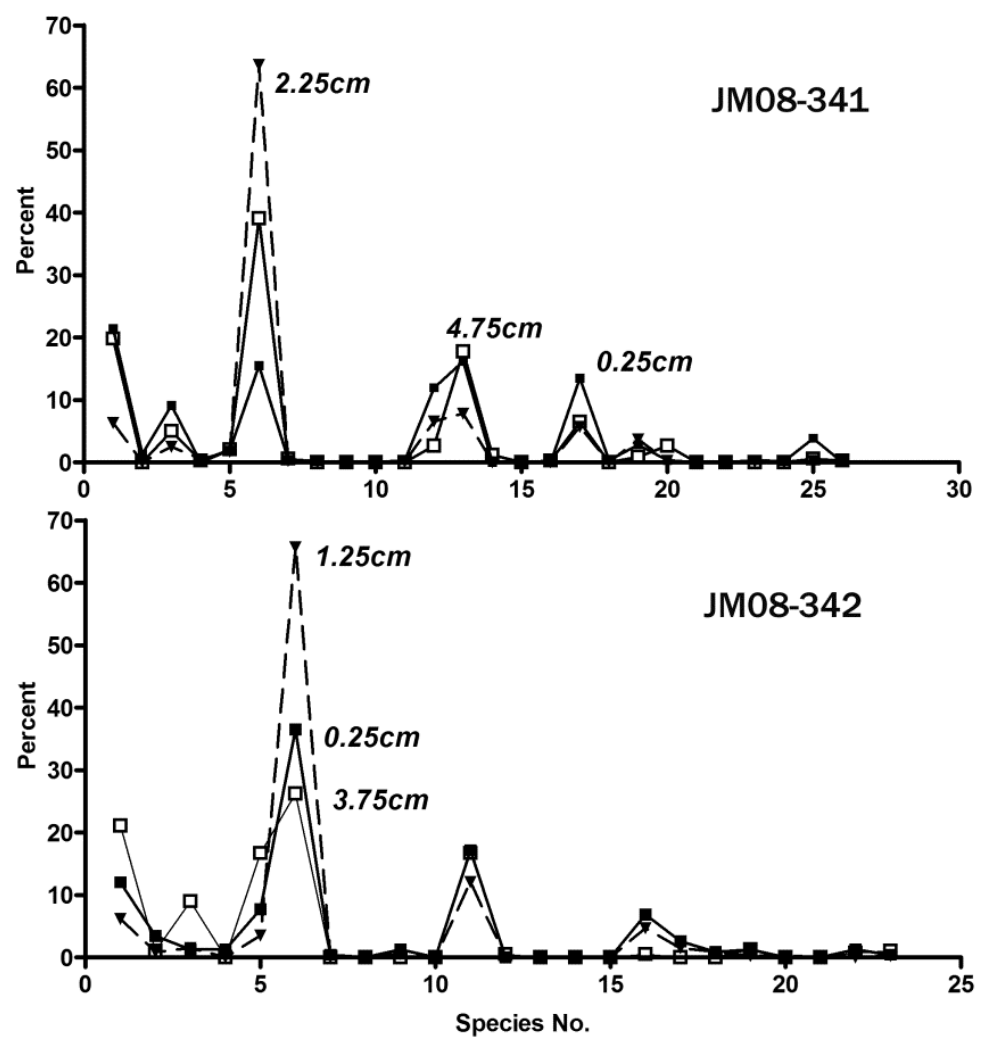

488
Figure 19. Taxon percents for abyssal sites. JM08-341: $1=$ C. wuellerstorfi, $3=$ C. pachyderma, $6=$ C. reniforme, $12=$ Miliola $\mathrm{sp} ., 13=$ Oridorsalis $\mathrm{sp} ., 17=$ E. exigua.

JM08-342: $1=C$. wuellerstorfi, $3=C$. pachyderma, $5=$ Gyroidina sp., $6=C$. reniforme, $11=$ Oridorsalis sp., $16=$ E. exigua. Complete taxon list in Appendix G.

Further insight to the developing benthic foraminiferal assemblage is provided by downcore assemblage correlation profiles (Fig. 20). A common feature of the correlation profiles is that greatest difference is found in the shallow subsurface between about 1 and $3 \mathrm{~cm}$ depth. Below this, assemblages are more similar to that of the surface. This curious pattern is due to the input of shallow infaunal production from relatively thin shelled taxa like C. reniforme. This input is attenuated through mixing and taphonomic process so that it becomes less significant with time (vertical distance above and below the production zone in the sediments). 


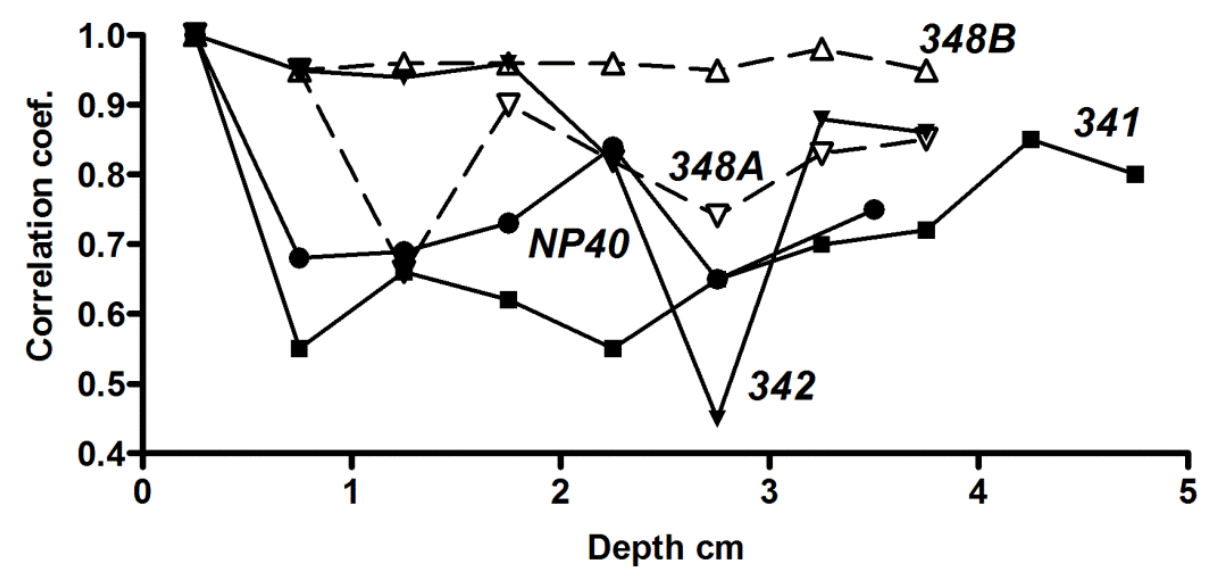

Figure 20. Correlation of downcore foraminiferal assemblages (taxon percents, total shell abundances) to the surface sediment assemblage. NP40 for Kongsfjord, 348A\&B for the continental slope and $341 \& 342$ for the abyssal plain.

There is considerable variation in assemblage correlation profiles (Fig. 20) both downcore and between profiles from the same location (e.g. WP08-348). This likely reflects the concentration of production at particular loci in the sediments, the variable rate of production on the smaller scale, and the variable and discontinuous nature of sediment mixing. For example, in the continental slope profile pair (WP08-348; Fig. 18) C. reniforme is much more abundant in one than the other (Fig. 13). This likely reflects concentrated production of this species at a particular location in the subsurface, in the recent past, which has not been well mixed into surrounding sediments, and which has not yet undergone extensive loss due to taphonomic processes.

Overall, there are significant differences between the surface sediment assemblage and those towards the base of the mixing zone. The effect appears largest in the fjord setting where there is considerable loss of shallow subsurface shell production and substantial deeper production with enhanced preservation within anoxic sediments. It is interesting that the setting with the greatest shell loss, the continental slope, does not end up with the greatest downcore change in 
514 assemblages. Apparently, the shell attenuation is roughly the same for the most common taxa 515 present.

\section{$516 \quad 6$. Conclusions}

517 Foraminiferal taxon total shell abundances from all the environments we sampled showed 518 often strong gradients within the bioturbation zone in near surface sediments. This is curious 519 since the ratio of sediment mixing rate to sedimentation rate will be high for the settings we 520 sampled. That means the sediments are mixing actively while material is accumulating on the 521 sea floor relatively slowly (on the order of 1 to $50 \mathrm{~cm} / \mathrm{kyr}$ ).

522 The abundance gradients we observed can be explained if the rates of shell production, and 523 destruction, are even higher than that of the bioturbation. In that case, gradients can be imposed 524 on the mixing zone. This is observed in pore water geochemical measurements which show 525 strong concentration gradients in well mixed sediments because reaction rates far exceed the 526 mixing rate. Foraminiferal shell dissolution is associated with geochemical reactions in the oxic 527 portion of the sediment column, so taphonomic rates should exceed sediment mixing rates. As

528 benthic foraminiferal standing stocks are observed to vary seasonally, production of shells is also 529 rapid compared to mixing rate or sedimentation rate. So, shell production and destruction rates 530 allow for a dynamic balance within the sediment mixing zone, and the existence of taxon 531 abundance gradients.

532 The abundance gradients that develop depend on location of taxon microhabitats and the 533 position of the anoxic boundary within the sediment mixing zone. In the settings we examined, 534 high organic carbon flux to the seabed (fjord) resulted in a shallow subsurface anoxic boundary 535 and significant foraminiferal production below this. Shell loss was strong for surficial 
536 foraminiferal production, but less so for production at depth. Assemblage formation was biased 537 to shell production deeper in the biologically active zone of the sediments.

538 On the continental slope, moderate organic carbon flux produced a well developed zone of oxic 539 respiration in which taphonomic shell loss was significant, so shell abundance downcore was 540 strongly attenuated. Fossil assemblage formation should be biased to the more robust taxa 541 producing in near surface sediments, and those taxa which have productive populations in the 542 lower part of the biologically active zone of the sediments. Low organic carbon flux to the 543 seabed of the abyssal plain yielded foraminiferal production and taphonomy concentrated in the 544 shallow subsurface. However, there was evidence for localized significant production by many 545 taxa in the lower part of the sediment mixing zone.

546 It remains possible that some taxon abundance variability in the sediment mixing zone could 547 result from responses to recent changes in environmental conditions in the northern North 548 Atlantic. Spielhagen et al. (2011) document such changes in the northern Fram Strait and show a 549 strong shallow sediment decrease in planktonic foraminiferal abundances in a deep sea core.

550 Interestingly, the large abundance gradient does not directly correlate to independent, 551 geochemical and instrumental, tracers of environmental change. Based on our work, it is 552 reasonable to propose that a significant part of the foraminiferal abundance gradient is due to 553 sediment mixing and diagenesis; factors not considered in the published work.

554 Nevertheless, it is clear that environmental change has occurred in the North Atlantic in the 555 past several centuries, and, since mixing and diagenesis are variable processes, some of that 556 change is reflected in the benthic foraminiferal abundance profiles we examined. It is unlikely

557 that the environmental change is the dominant cause of our abundance profiles since an

558 abundance of research has demonstrated the nature of sediment mixing and carbonate diagenetic 
processes in marine sediments. Further, the gradients we observe fit well with expectations for the mixing process combined with our knowledge of taxon microhabitats and diagenetic reactions in the sediments based on measured pore water oxygen concentration profiles. Finally, we examined cores which undoubtedly have quite different sedimentation rates, but we find abundance changes occurring at similar depths in all of them (e.g. Fig. 20). If the abundance

564 gradients were driven by regional environmental change then we would expect to see gradients developing at different depths in different cores, depending on rates of sediment accumulation at

566 different sites.

567 The results imply that, across the range of environments sampled, the interplay of shell production and destruction through the sediment mixing zone produces fossil assemblages which

569 can be significantly different from both the standing stock and the assemblage at the sediment surface. Generally, there is a bias towards the preservation of shells which are produced deeper

571 in the sediment profile, or the portion of the taxon's production which occurred deeper in the 572 sediments. Only further research will show the extent to which the processes we have attempted to examine affect assemblage formation broadly across the open ocean realm. 


\section{References}

591

592

593

594

595

596

597

598

599

600

601

602

603

604

605

606

607

608

609

610

611

612

613

614

615

616

617

618

619

620

621

622

623

624

625

626

627

628

629

630

631

632

633

634
Aller, R., 1982, Carbonate dissolution in nearshore terrigenous muds: The role of physical and biological reworking, Journal of Geology, 90, 79-95.

Alve, E., Murray, J.W., 1997. High benthic fertility and taphonomy of foraminifera: a case study of the Skagerrak, North Sea. Marine Micropaleontology 31, 157-175.

Alve, E., Murray, J., and Skei, J., 2011, Deep-sea benthic foraminifera, carbonate dissolution and species diversity in Hardangerfjord, Norway: An initial assessment, Estuarine, Coastal and Shelf Science, 92, 90-102.

Archer, D., Emerson, S., and Reimers, C., 1989, Dissolution of calcite in deep-sea sediments: pH and $\mathrm{O}_{2}$ microelectrode results, Geochim. Cosmochim. Acta, 53, 2831-2845.

Bernhard, J., Ostermann, D., Williams, D., and Blanks, J., 2006, Comparison of two methods to identify live benthic foraminifera: A test between rose Bengal and Cell Tracker Green with implicaitons for stable isotope paleoreconstructions, Paleoceanography 21 (PA4210), 8.doi: 10.1029/2006PA001290.

Boltovskoy, E., and Wright, R., 1976, Recent Foraminifera, Springer Publishing, NY, 515p.

Carignan, J., Hillaire-Marcel, C., and De Vernal, A., 2008, Arctic vs. North Atlantic water mass exchanges in Fram Strait from Pb isotopes in sediments, Can. J. Earth Sci., 45, 1253-1263.

Cedhagen, Thomas, 2006. Foraminifera in the Northeast Atlantic and Arctic Oceans, Afdeling for Marin Okologi, Aarhus Universitet, 1-331.

Chung, S., Lee, K., Feely, R., Sabine, C., Millero, F., Wanninkhof, R.,Bullister, J., Key, R., and Peng, T., 2003, Calcium carbonate budget in the Atlantic Ocean based on water column inorganic carbon chemistry, Global Biogeochemical Cycles, 17(4), 1093, doi:10.1029/2002GB002001, 2003

Conkright, S., Levitus, S., Boyer, T., 1994, World Ocean Atlas, National Oceanographic Data Center, NOAA, Washington D.C., www.esrl.noaa.gov/psd/data.nodc.woa94.html

Denne, R., and Sen Gupta, B., 1989, Effects of taphonomy and habitat on the record of benthic foraminifera in modern sediments, PALAIOS, 4, 414-423.

Dijkstra, N., 2009. The Holocene deglaciation history of two (sub-) Arctic fjord systems- A comparison of modern and Holocene sedimentation processes in Kongsfjorden (NW Svalbard) and Disko Bay (W Greenland). Master Thesis, VU University Amsterdam, Netherlands, pp. 90.

Douglas, R., Liestman, J., Walch, C., Blake, G., and Cotton, M., 1980, The transition from live to sediment assemblage in benthic foraminifera from the Southern California borderland, Pacific 
661

662

663

664

665

666

667

668

669

670

671

672

673

674

675

676

677

678

679

Coast Paleogeography Symposium 4, Pacific Section of the Society of Economic Paleontologists and Mineralogists, p. 257-280.

Duros, P., Fontanier, C., de Stigter, H.C., Cesbron, F., Metzger, E., and Jorissen, F., 2012, Live and dead benthic foraminiferal faunas from Whittard Canyon (NE Atlantic): Focus on taphonomic processes and paleo-environmental applications, Marine Micropaleontology, 94-95, $25-44$.

Elverhoi, A., Lonne, O., and Seland, R., 1983, Glaciomarine sedimentation in a modern fjord environment, Spitsbergen, Polar Research, 1, 127-149.

Emerson, S., and Bender, L., 1981, Carbon fluxes at the sediment-water interface of the deep sea: Calcium carbonate preservation, Journal of Marine Research, 39, 139-162.

Froelich, P., Klinkhammer, G., Bender, M., Luedtke, N., Heath, G., Cullen, D., and Dauphin, P., 1979, Early oxidation of organic matter in pelagic sediments of the eastern equatorial Atlantic: suboxic diagenesis, Geochimica et Cosmochimica Acta, 43, 1075-1090.

Goloway, F., and Bender, M., 1982, Diagenetic models of interstitial nitrate profiles in deep sea suboxic sediments, Limnology and Oceanography, 27, 624-638.

Guinasso, N., and Schink, D., 1975, Quantitative estimates of biological mixing rates in abyssal sediments, Journal of Geophysical Research, 80, 3032-3043.

Hald, and Steinsund, P., 1996, Benthic foraminifera and carbonate dissolution in surface sediments of the Barents and Kara Seas, In: Surface sediment composition and sedimentary processes in the central Arctic Ocean and along the Eurasian continental margin (Stein, R., Ivanov, G., Levitan, M., and Fahl, K., eds.), p. 285-307, Berichte zur Polarforschung 212 (ISSN 0176-5027).

Husum, K., and Hald, M., 2002. Early Holocene cooling events in Malangenfjord and the adjoining shelf, north-east Norwegian Sea. Polar Research 21, 267-274.

Jahnke, R., Craven, D., and Gaillard, J., 1994, The influence of organic matter diagenesis on $\mathrm{CaCO}_{3}$ dissolution at the deep-sea floor, Geochimica et Cosmochimica Acta, 58, 2799-2809.

Jernas, P., 2012. Benthic foraminifera in an Arctic fjord: recent distribution and fauna of the last two millennia. Ph.D. Thesis. University of Tromsø, Norway, ISBN 978-82-8236-070-8.

Jernas, P., Klitgaard Kristensen, D., Husum, K., Wilson, L., and Koç, N., 2013.

Paleoenvironmental changes of the last two millennia on the western and northern Svalbard shelf. Boreas 42, 236-255.

Jorissen, Frans J., Henko C. de Stigter, and Joen G. V. Widmark. (1995). A conceptual model explaining benthic foraminiferal microhabitats, Marine Micropaleontology, v. 26, Issues 1-4, 315. 
Jorissen, F., 1999, Benthic Foraminiferal Microhabitats Below the Sediment-Water Interface, In: Modern Foraminifera (Sen Gupta, B., ed.), p. 161-180, Springer Science, Dordrecht, Netherlands, 374pp.

Korsun, S., and Hald, M., 2000. Seasonal dynamics of benthic foraminifera in a glacially fed fjord of Svalbard, European Arctic. Journal of Foraminiferal Research 30 (4), 251-271.

Kotwicki, L., Szymelfenig, De Troch, M., and Zajaczkowski, M., 2004, Distribution of meiofauna in Kongsfjorden, Spitzbergen, Polar Biology, 27, 661-669.

Loeblich, A.R., Jr., and Tappan, H., 1953. Studies of Arctic Foraminifera. Smithsonian Miscellaneous Collections 121, 1-150.

Loubere, P., 1989, Bioturbation and sedimentation rate control of benthic microfossil taxon abundances in surface sediments: a theoretical approach to the analysis of species microhabitats, Marine Micropaleontology, 14, 317-325.

Loubere, P., and Gary, A., 1990, Taphonomic process and species microhabitats in the living to fossil assemblage transition of deeper water benthic foraminifera, Palaios, 5, 375-381.

Loubere, P., Gary, A., and Lagoe, M., 1993, Benthic Foraminiferal microhabitats and the generation of the Fossil assemblage: Theory and preliminary data, Marine Micropaleontology, $\underline{20}$, p. $165-181$.

Loubere, P., 1997, Benthic foraminiferal assemblage formation, organic carbon flux, and oxygen concentrations on the outer continental shelf and slope, J. of Foraminiferal Research, 27, 93-100.

Loubere, P., Jacobsen, B., Klitgaard-Kristensen, D., Husum, K., Jernas, P., and Richaud, M., 2011, The structure of benthic environments and the paleochemical record of benthic foraminifera, Deep Sea Research I, 58, 535-545.

Mackensen, A., Sejrup, H.P., Jansen, E., 1985. The distribution of living benthic foraminifera on the continental slope and rise off southwest Norway. Marine Micropalaeontology 9, 275-306

Mackensen, A., and Douglas, R., 1989, Down-core distribution of live and dead deep-water benthic foraminifera in box cores from the Weddell Sea and the California continental borderland, Deep Sea Research, 36, 879-900.

Mackensen, A., Schmiedl, G., Harloff, J., Giese, M., 1995. Deep-sea foraminifera in the South Atlantic Ocean. Ecology and assemblage generation. Micropaleontology 41 (4), 342-358.

Martin, R., 1999, Taphonomy and the temporal resolution of Foraminiferal assemblages, In: Modern Foraminifera (Sen Gupta, B., ed.), p. 281-298, Springer Science, Dordrecht, Netherlands, 374pp. 
Murray, 1976, Comparative studies of living and dead benthic foraminiferal distributions. In: Hedley R.H., and Adams, C.G. (eds) Foraminifera 2: 45-109 (Academic Press).

Murray, J.W., 1991. Ecology and Palaeoecology of Benthic Foraminifera. Longman. 397 pp.

Murray, J.W., and Alve, E., 1999. Natural dissolution of modern shallow water benthic foraminifera: taphonomic effects on the palaeoecological record. Palaeogeography, Palaeoclimatology, Palaeoecology 146, 195 e209.

Norgaard-Pedersen, and N., Mikkelsen, N., 2009, 8000 year marine record of climate variability and fjord dynamics from Southern Greenland. Marine Geology 264, 177-189.

Rasmussen, Tine Lander; Thomsen, Erik; Slubowska-Woldengen, Marta; Slubowska, Martha; Jessen, Simon; Solheim, Anders; Koc, Nalan, 2007, Paleoceanographic evolution of the SW Svalbard margin (76 degrees N) since 20,000 C-14 yr BP. Quaternary Research, 67. 100 - 114, doi: $10.1016 /$ j.yqres.2006.07.002.

Reaves, C., 1986, Organic carbon metabolizability and calcium carbonate dissolution in nearshore muds, Journal of Sedimentary Petrology, 56, 486-494.

Sarmiento, J., and Gruber, N., 2006, Ocean Biogeochemical Dynamics, Princeton University Press, Princeton, N.J., 503p.

Scott, D., and F. Medioli, 1980, Living vs. total foraminiferal populations, their relative usefulness in paleoecology, J. Paleontology, 54, 814-831.

Skirbekk, K., Klitgaard Kristensen, D., Rasmussen, T. L., Koç, N., Forwick, M., 2010. Holocene climate variations at the entrance to a warm Arctic fjord: evidence from Kongsfjorden trough, Svalbard, in: Fjord Systems and Archives, edited by: Howe, J. A., Austin, W. E. N., Forwick, M., and Paetzel, M., Geological Society of London, Special Publications, 344, London, pp. 289304.

Ślubowska-Woldengen, M., Koç, N., Rasmussen, T.L., Klitgaard-Kristensen, D., Hald, M., Jennings, A.E., 2008. Time-slice reconstructions of ocean circulation changes at the continental margins of the Nordic and Barents Seas during the last 16,000 cal yr B.P. Quaternary Science Reviews, 27, 1476-1492

Smith, R., 1987, Fossilization potential in modern shallow water benthic foraminiferal assemblages, Journal of Foraminiferal Research, 17, 117-122.

Spielhagen, R., Werner, K., Sorensen, S., Zamelczyk, K., Kandiano, E., Budeus, G., Husum, K., Marchitto, T., and Hald, M., 2011, Enhanced modern heat transfer to the Arctic by warm Atlantic water, Science, 331, 450-453, doi:10.1126/Science.1197397. 
Stein, R., 1996, Organic-carbon and carbonate distribution in Eurasian continental margin and Arctic Ocean deep-sea surface sediments: Sources and pathways, In: Surface sediment composition and sedimentary processes in the central Arctic Ocean and along the Eurasian continental margin (Stein, R., Ivanov, G., Levitan, M., and Fahl, K., eds.), p. 243-267, Berichte zur Polarforschung 212 (ISSN 0176-5027).

Steinsund, P.I., Hald, M., 1994. Recent calcium carbonate dissolution in the Barents Sea: Paleoceanographic applications. Marine Geology 117, 303-316.

Svendsen, H., Beszczynska-Moller, A., Hagen, J.O., Lefauconnier, B., Tverberg, V., Gerland, S., Orbaek, J.B., Bischof, K., Papucci, C., Zajączkowski, M., Azzolini, R., Bruland, O., Wiencke, C., Winther J., Dallman, W., 2002. The physical environment of Kongsfjorden-Krossfjorden, and Arctic fjord system in Svalbard, Polar Research 21, 133-166.

Wassman, P., 2001, Vernal export and retention of biogenic matter in the northeastern North Atlantic and adjacent Arctic Ocean: The role of the Norwegian Atlantic Current and topography, Mem. National Polar Research Specifications (54), 337-392.

Wlodarska-Kowalczuk, M., and Pearson, T., 2004, Soft-bottom macrobenthic faunal associations and factors affecting species distributions in an Arctic glacial fjord (Kongsfjord, Spitsbergen), Polar Biology, 27, 155-167.

Wollenburg, J., 1995, Benthic foraminiferal assemblages in the Arctic Ocean: indicators for water mass distribution, productivity, and sea ice drift, Berichte zur Polarforschung, 179 (ISSN 0176-5027), 228p.

Wollenburg, J., and Mackensen, A., 1998, On the vertical distribution of living (Rose Bengal stained) benthic foraminifers in the Arctic Ocean, Journal of Foraminiferal Research, v. 28, no. 4, 268-285.

Zaborska, A., Pempkowiak, J., and Papucci, C., 2006, Some sediment characteristics and sedimentation rates in an Arctic Fjord (Kongsfjorden, Svalbard), Środkowo-Pomorskie Towarzystwo Naukowe 96 Ochrony Środowiska, Tom 8. Rok ,79-97. 